Информация для цитирования:

Телегин А. С., Тиунова Н. В. Повторность совершения административного правонарушения // Вестник Пермского университета. Юридические науки. 2019. Вып. 46. С. 626-650. DOI: 10.17072/1995-4190-2019-46$626-650$

Telegin A. S., Tiunova N. V. Povtornost' soversheniya administrativnogo pravonarusheniya [Repetition of Administrative Offenses]. Vestnik Permskogo universiteta. Juridicheskie nauki - Perm University Herald. Juridical Sciences. 2019. Issue 46. Pp. 626-650. (In Russ.). DOI: 10.17072/1995-4190-2019-46-626-650

удК 342.95

DOI: 10.17072/1995-4190-2019-46-626-650

\title{
ПОВТОРНОСТЬ СОВЕРШЕНИЯ
}

\section{АДМИНИСТРАТИВНОГО ПРАВОНАРУШЕНИЯ}

\section{А. С. Телегин}

Кандидат юридических наук, профессор,

ав. кафедрой конституционного и финансового права

Пермский государственный

й исследовательский университе

614990, Россия, г. Пермь, ул. Букирева, 15

ORCID: 0000-0001-6944-2577

E-mail: telegin.a49@yandex.ru

\section{Н. В. Тиунова}

Кандидат юридических наук, доцент,

доцент кафедры конституционного и финансового права

Пермский государственньй

ациональный исследовательский университет

614990, Россия, г. Пермь, ул. Букирева, 15

ORCID: 0000-0002-8985-3653

E-mail: nvt888@mail.ru

\section{Поступила в редакцию 15.06 .2019}

Введение: рассиатривается вопрос о нногообразии нориативного регулирования по смыслу и содержсанию повторности в современных условиях правоприменительной практики органов исполнительной и судебной власти, осуществляющих производство по делам об административных правонарушениях. Анализ норм действующего Кодекса Российской Федерачии об административных правонарушениях свидетельствует о том, что повторность применяется в качестве обстоятельства, отягчающего административную ответственность, а также как самостоятельный квалифицирующий признак составов административных правонарушений и критерий для определения понятия гру бого проступка. Наряду с этим повторность совершения административного правонарушения является административно-преюдиииальным признаком для квалификаиии дея-

\section{A. S. Telegin}

Perm State University

5, Bukireva st., Perm, 614990, Russia

ORCID: 0000-0001-6944-2577

E-mail: telegin.a49@yandex.ru

\section{N. V. Tiunova}

erm State University

15, Bukireva st., Perm, 614990, Russia

ORCID: 0000-0002-8985-3653

E-mail:nvt888@mail.ru

\section{Received 15.06.2019}

Introduction: the article deals with the concept of repetition, problems of its statutory regulation and application in law enforcement practice by the executive and judicial bodies carrying out administrative proceedings. The main focus is on the problem of the variety of approaches to defining the legal sense and content of this concept. Analysis of the norms of the current Code of Administrative Offenses of the Russian Federation (RF CAO) shows that repetition is applied as a circumstance that aggravates administrative liability, as an independent qualifying characteristic of the elements of offense, and as a criterion for defining a gross misconduct. At the same time, repeat commitment of an administrative offense is an administrative-prejudicial criterion for qualifying the act as a crime. In each of the above cases of applying the repetition, there is a number of problematic aspects which require a more focused attention of the legislator. This refers, first, to the legal meaning of the concept of similar nature and analogousness of the administrative offense commitmen for applying repetition in compliance with the RF CAO, and second, to the necessity of le-

(c) Telegin A. S., Tiunova N. V., 2019 
ния в качестве преступления. В каждом из вышеназванных случаев применения повторности существует ряд проблемных аспектов, требующих более пристального внимания со стороны законодателя. Речь идет о юридическом значении понятия однородности и аналогичности совершения административного проступка при применении повторности в соответствии с КоАП РФ, а также о необходимости правовой регламентаиии содержсания данных понятий непосредственно в законе, а не в акте судебного толкования. Вместе с тем возникает вопрос о иелесообразности существования в КоАП РФ ин-

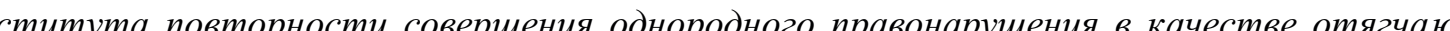
щего обстоятельства наряду с тенденцией увеличения количества составов, содержащих повторность в качестве самостоятельного квалифицирующего признака. Актуальным также является вопрос о понятии и видах неоднократности при применении повторности в качестве административно-преюдииального признака для квалификаиии рголовно наказуелых делий. Для квалификачии преступления в некоторых сличая достаточно однократного совершения административного правонарушения, а в других закреплена многократность проступков (например, дважды и более двух раз). Во многих случаях критерии и признаки неоднократности применяются с учетом практики судебного толкования без конкретизации в законе. Важным критерием для применения административно-преюдициальных норм при квалификации преступлений является совершение аналогичного деяния личом, ранее подвергнутым административному наказанию период, который предусмотрен статьей 4.6 КоАП РФ. Практика применения данной нормы весьма неоднозначна, поскольку в Уголовном кодексе Российской Федерации не всегда этот срок конкретизируется со ссылкой на данную статью. Цель: обосновать актуальность избранной темы исследования; дать сравнительный анализ нормативного регулирования повторности в производстве по делам об административных правонарушениях и научных подходов к пониманию юридческого смысла понятия «повторность»; показать проблемные аспекты, возникающие на практике при применении повторности для квалификации деяний и ремения вопроса о назначении наказаний. Методы: диалектический метод как универсальный научный инструмент; общенаучные (анализ, синтез, обобщение, сравнение, системно-структурный анализ) и частнонаучные (формальноюридический, формально-логический, структурно-функииональный) методы познания. Результаты: внесены конкретные предложения по совершенствованию современного законодательства России, которые позволят оптимизировать прочесс квалификаиии составов повторных административных правонарушений, в том числе при применении административно-преюдиииальных норм в уголовном законодательстве России. Выводы: многообразие юридического содержания повторности совершения административных правонарушений порождает необходимость в комплексном изучении правовой природы данного вопроса и практики его применения, а также позволяет вести речь о дальнейших перспективах совершенствования и систематизации норм КоАП РФ и УК $P \Phi$, регулирующих правила применения повторности при квалификации деяний и назначении наказаний.

Ключевые слова: повторность совершения административного правонарушения; административная преюдиция; неоднократность; аналогичное деяние; уголовная ответственность за неоднократно или повторно совершенные административные правонарушения gal regulation for the content of these notions directly in law but not in an act of judicial interpretation. There arises a question about the feasibility of having the institution of repeat commitment of analogous crime in the RF CAO as an aggravating circumstance together with the tendency of increasing the number of the crime elements containing repetition as an independent qualifying characteristic. Another important question is about the concept and the types of duplicity when applying repetition as an administrative-prejudicial criterion for qualifying acts punishable under criminal law. In some cases, a single commitment of an offense is enough for qualifying it; in other cases, offenses need to be committed several times (for example, twice or thrice). In many cases, criteria and signs of repetition are applied taking into account the judicial interpretation practice, with no specification in law. An important criterion for applying administrative-prejudicial norms in qualifying offenses is commitment of a similar offense by a person who previously underwent administrative punishment within the period established by Article 4.6 of the RF CAO. The practice of this norm application is rather questionable as the Criminal Code of the Russian Federation does not always specify this period with reference to Article 4.6 of the RF CAO. Purpose. to justify the current relevance of the chosen research topic; to provide a comparative analysis of statutory regulation of repetition in administrative proceedings and scientific approaches to understanding the legal meaning of the 'repetition' concept; to show problematic aspects arising in practice when the concept of repetition is used for qualifying offenses and taking decisions on the punishment. Methods: dialectical method as a universal scientific instrument, general scientific methods (analysis, synthesis, generalization, comparison, systemic and structural analysis) and specific scientific methods (formal juridical, formal logical, structural functional). Results: the authors have formulated specific proposals aimed at improving modern legislation in Russia. The proposed measures would allow for optimizing the process of qualifying repeat administrative offenses, including when administrative-prejudicial norms are applied. Conclusions: the concept of repetition of administrative offenses, its legal content and practice of application require complex investigation. There is a need for further improvement and systematization of the RF CAO and $R F$ Criminal Code norms that regulate the rules of applying repetition when qualifying offenses and awarding punishment.

Keywords: repeat administrative offense; administrative prejudice; duplicity; analogous offense; criminal liability for multiple or repeat administrative offense 


\section{Information in Russian}

\section{ПОВТОРНОСТЬ СОВЕРШЕНИЯ АДМИНИСТРАТИВНОГО ПРАВОНАРУШ ЕНИЯ}

\section{A. S. Telegin}

Perm State University

15, Bukireva st., Perm, 614990, Russia

ORCID: 0000-0001-6944-2577

E-mail: telegin.a49@yandex.ru

\section{N. V. Tiunova}

Perm State University

15, Bukireva st., Perm, 614990, Russia

ORCID: 0000-0002-8985-3653

E-mail: nvt888@mail.ru

\section{Received 15.06.2019}

Introduction: the article deals with the concept of repetition, problems of its statutory regulation and application in law enforcement practice by the executive and judicial bodies carrying out administrative proceedings. The main focus is on the problem of the variety of approaches to defining the legal sense and content of this concept. Analysis of the norms of the current Code of Administrative Offenses of the Russian Federation (RF CAO) shows that repetition is applied as a circumstance that aggravates administrative liability, as an independent qualifying characteristic of the elements of offense, and as a criterion for defining a gross misconduct. At the same time, repeat commitment of an administrative offense is an administrativeprejudicial criterion for qualifying the act as a crime. In each of the above cases of applying the repetition, there is a number of problematic aspects which require a more focused attention of the legislator. This refers, first, to the legal meaning of the concept of similar nature and analogousness of the administrative offense commitment for applying repetition in compliance with gousness of the administrative offense commitment for applying repetition in compliance with
the RF CAO, and second, to the necessity of legal regulation for the content of these notions directly in law but not in an act of judicial interpretation. There arises a question about the feasibility of having the institution of repeat commitment of analogous crime in the RFCAO as an aggravating circumstance together with the tendency of increasing the number of the crime elements containing repetition as an independent qualifying characteristic. Another important question is about the concept and the types of duplicity when applying repetition as an administrative-prejudicial criterion for qualifying acts punishable under criminal law. In some cases, a single commitment of an offense is enough for qualifying it; in other cases, offenses need to be committed several times (for example, twice or thrice). In many cases, criteria and signs of repetition are applied taking into account the judicial interpretation practice, with no specification in law. An important criterion for applying administrative-prejudicial norms in qualifying offenses is commitment of a similar offense by a person who previously underwent administranorm application is rather questionable as the Criminal Code of the Russian Federation does not always specify this period with reference to Article 4.6 of the RF CAO. Purpose: to justify the current relevance of the chosen research topic; to provide a comparative analysis of statutory regulation of repetition in administrative proceedings and scientific approaches to understanding the legal meaning of the 'repetition' concept; to show problematic aspects arising in practice when the concept of repetition is used for qualifying offenses and taking decisions on the punishment Methods: di tific methods (analysis, synthesis, generalization, comparison, systemic and structural analysis, and specific scientific methods (formal juridical, formal logical, structural functional). Results: the authors have formulated specific proposals aimed at improving modern legislation

\section{А. С. Телегин}

Кандидат юридических наук, профессор,

зав. кафедрой конституционного и финансового права

Пермский государственный национальный исследовательский университет

614990, Россия, г. Пермь, ул. Букирева, 15

ORCID: 0000-0001-6944-2577

E-mail: telegin.a49@yandex.ru

\section{Н. В. Тиунова}

Кандидат юридических наук, дощент,

доцент кафедры конституционного и финансового права

Пермский государственный национальный исследовательский университет

614990, Россия, г. Пермь, ул. Букирева, 15

ORCID: 0000-0002-8985-3653

E-mail: nvt888@mail.ru

\section{Поступила в редакцию 15.06.2019}

Введение: рассматривается вопрос о многообразии нормативного регулирования по смысслу и содержанию повторности в современных условиях правоприменительной практики органов исполнительной и судебной власти, осуществляюших производство по делам об административных правонарушениях. Анализ норм действующего Кодекса Российской Федерации об административных правонарушениях свидетельствует о том, что повторность применяется в качестве обстоятельства, отягчающего административную ответственность, а также как самостоятельный квалифицирующий признак составов административных правонарушений и критерий для определения понятия грубого проступка. Наряду с этим повторность совершения административного правонарушения является административно-преюдициальным признаком для квалификаиии деяния в качестве преступления. В каждом из вышеназванных случаев применения повторности существует ряд проблемных аспектов, требующих более пристального внимания со стороны законодателя. Речь идет о юридическом значении понятия однородности и аналогичности совершения административного проступка при применении повторности в соответствии с КоАП РФ, а также о необходимости правовой регламентаиии содержания данных понятий непосредственно в законе, а не в акте судебного толкования. Вместе с тем возникает вопрос о иелесообразности существования в КоАП РФ института повторности совершения однородного правонарушения в качестве отягчающего обстоятельства наряду с тенденииеи увеличения количества составов, содержащих повторность в качестве самостоятельного квалифичирующего признака. Актуальным также является вопрос о понятии и видах неоднократности при применении повторности в качестве административно-преюдицильного признака для квалификации уголовно наказуемых деяний. Для квалификачии преступления в некоторых случаях достаточно однократного совершения административного правонарушения, а в других - закреплена многократность проступков (например, дважды и более двух раз). Во многих случаях критерии и признаки неоднократности применяются с учетом практики судебного толкования без конкретизаиии в законе. Важным критерием для применения административно-преюдиииальных норм при квалификаиии преступлений является совершение аналогичного деяния лииом, ранее подвергнутым административному наказанию в период, который предусмотрен статьей 4.6 КоАП РФ. Практика применения данной нормы весьма неоднозначна, поскольку в Уголовном кодексе Российской Федерачии не всегда этот срок конкретизируется со ссылкой на данную статью. Цель: обосновать актуальность избранной темы исследования; дать сравнительный анализ нормативного регулирования повторности в производстве по делам об административных правонарушениях и научных подходов к пониманию юридического смысла понятия «повторность»; показать проблемные аспекты, возникающие на практике при применении повторности для квалификации деяний и рещения вопроса о назна- 
in Russia. The proposed measures would allow for optimizing the process of qualifying repeat administrative offenses, including when administrative-prejudicial norms are applied. Conclusions: the concept of repetition of administrative offenses, its legal content and practice of application require complex investigation. There is a need for further improvement and systemati zation of the RFCAO and RF Criminal Code norms that regulate the rules of applying repetition when qualifying offenses and awarding punishment.

Keywords: repeat administrative offense; administrative prejudice; duplicity; analogous offense; criminal liability for multiple or repeat administrative offense

\section{Введение}

Правовая природа законодательного подхода к ужесточению карательной функции государства за повторно совершенные деяния впервые заявила о себе еще в дореволюционной России с принятием Соборного Уложения 1649 года, в котором было введено понятие рецидива. Тенденция усиления карательной политики была продолжена при Петре I, что было положено в основу уголовного законодательства. Впоследствии признак повторности совершения деяния был воспринят при квалификации дисциплинарных и административных проступков, заняв укрепительные позиции в распространении административно-преюдициальных норм в современном уголовном законодательстве России.

Повторность совершения противоправных деяний в 1920-х годах в РСФСР имела важно значение для квалификации и последовательного применения более строгих мер государственного принудительного воздействия. Так например, Декретом ВЦИК, СНК РСФСР от 26 апреля 1920 г. «О мерах воздействия за неаккуратное посещение заседаний и совещаний» было закреплено, что опоздание членов Исполнительных Комитетов и служащих в советских учреждениях на постоянные заседания «первый раз более чем на 10 минут влечет за собой выговор с занесением в протокол заседания, второй раз - вычет дневного заработка, как за прогул, а в 3-й раз - выговор в печати. Опоздавшие свыше 3-х раз подряд привлекаются на основании Постановления Всероссийского Центрального Исполнительного Комитета и Совета Народных Комиссаров о дисциплинарных и административных взысканиях».

'О мерах воздействия за неаккуратное посещение засед

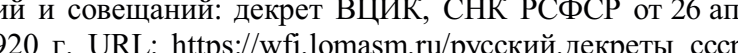
1917-1992.(30-8) (дата обращения: 10.06.2019).
В эти же годы юридическое содержание неоднократной повторности совершения дисциплинарного проступка применялось и для квалификации деяния в качестве преступления В соответствии с пунктом 10 Декрета ВЦИК от 18 марта 1920 г. «О Революционных Военных Железнодорожных Трибуналах», было установлено, что «дела о всякого рода преступлениях железнодорожных служащих, связанные с нарушением правильной работы железных дорог или препятствующие восстановлению нормальной деятельности железнодорожного транспорта, к числу каковых дел относятся все виды умышленного и корыстного посягательства как на имущество железнодорожного, та и на вверенное дорогам для перевозки и не только умышленное неисполнение служебных обязанностей (саботаж), но и явно небрежное к ним отношение в случаях, имеющих для трансорта важные последствия, как и при повторении упущений после двухкратного взыскания дисциплинарном порядке» ${ }^{2}$.

По декрету Совета Народных Комиссаров от 7 октября 1921 г. «Об ответственности за нарушение декрета о продаже виноградных, плодово-ягодных и изюмных вин», за впервые совершенное нарушение оптовой и розничной орговли лица привлекались к ответственности административном порядке на основании декрета Совета Народных Комиссаров «Об административных взысканиях» 1921 года, а за совершение нарушений во второй раз лицо каралось в судебном порядке 3 .

O Революционных Военных Железнодорожных Трибуналах): декрет ВЦИК от 18 марта 1920 г. URL:

mix.ru/sssr//18623 (дата обращения: 10.06 .2019$)$.
3 Об ответственности за нарушение декрета о продаже Об ответственности за нарушение декрета о продаже
виноградных, плодово-ягодных и изюмных вин»: еекрет Овета Народных Комиссаров от 7 окт. 1921 г.; Об адмиродных Комиссаров. URL: https://wfil lomasm ru/pycскй. декреты_ссср_1917-1992 (дата обращения: 10.06.2019).

чении наказаний. Методы: диалектический метод как универсальный научный инстру мент; общенаучные (анализ, синтез, обобщение, сравнение, системно-структурный анализ) и частнонаучные (формально-юридический, формально-логический, структурнофункииональный) методы познания. Результаты: внесены конкретные предложения по совериенствованию современного законодательства России, которые позволят оптимизировать процесс квалификации составов повторных административных правонарушений, в том числе при применении административно-преюдициальных норм в уголовном законодательстве России. Выводы: многообразие юридического содержания повторности совериения административных правонаруиений порождает необходимость в комплексном изучении правовой природы данного вопроса и практики его применения, а также позволяет вести речь о дальнейших перспективах совериенствования и систематизаиии норм КоАП РФ и УК РФ, регулирующих правила применения повторности при квалификаиии деяний и назначении наказаний.

Ключевые слова: повторность совершения административного правонарушения;

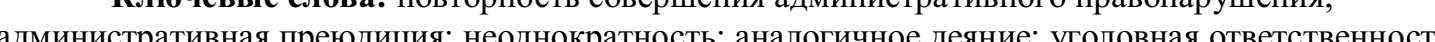

за неоднократно или повторно совершенные административные правонарушения

\section{Introduction}

The legal nature of the legislative approach to reinforcing the punitive function of the state for repeatedly committed offenses first manifested itself as far back as in pre-revolutionary Russia, when the Council Code of 1649 was adopted, which introduced the concept of repetition. The tendency of reinforcing the punitive policy continued at the times of Peter the Great and formed the fundamentals of criminal legislation. Later the concept of offense repetition extended to disciplinary and administrative offenses and got firm positions in spreading administrative-prejudicial norm in the modern criminal legislation of Russia.

The repetition of offenses was of significan importance in the RSFSR in the 1920s for the qualification and consistent application of stricter coercive measures by the state. For example, Decree of the All-Russian Central Executive Committee, Council of People's Commissars of RSFSR 'On Enforcement Measures for Inaccurate Attendance of Meetings and Sessions' of April 26, 1920 ran that late arrival (coming more than 10 minutes ran that late arrival (coming more than 10 minutes late) of the members of Executive Committees an employees of the Soviet organizations at regular sessions results in a reprimand to be placed into first time of first time, being late for the second time results in deduction of daily salary (the same as for being absent), being late for the third time leads to a reprimand in print media. Those being late more than 3 times in succession held liable on the basis of the Resolution of the All-Russian Central Executive Committee and the Council of People's Commissars on disciplinary and administrative penalties

${ }^{1}$ Decree of the All-Russian Central Executive Committee and
Council of People's Commissars of April 26, 1920 'On EnCouncil of People's Commissars of April 26, 1920 'On En-
forcement Measures for Inaccurate Attendance of Meetings forcement Measures for Inaccurate Attendance of 'Meetings
and Sessions'. Available at: http//wfillomasm.ru/ pyccкий
декреть_ccep_1917-1992.(30-8) (accessed 20.10.2019).
In the same years, the legal content of the multiple repetition of a disciplinary offense was also used for qualifying an action as being a crime. Item 10 of Decree by the All-Russian Central Executive Committee of March 18, 1920 'On Revolutionary Military Railway Tribunals' established that 'the cases of different kinds of offenses committed by railway service officers associated with the breakage of the correct functioning of railways or preventing from the restoration of the normal operation of the railway transport, including all types of deliberate and mercenary offenses against the railway property and the property entrusted to the railway service for transportation, and not only deliberate failure to perform official duties (sabotage) but also flagran negligent attitude to the duties in cases having significant consequences for the transportation, as e repetition after uble disciplinary punishment'

According to the Decree of the Council of People's Commissars of October 7, 1921 On the Liability for Violating the Decree on Selling Grape, Fruit-Berry and Raisin Vines', for the first offense committed in wholesale and retail trade, individuals were brought to administrative liability in accordance with the Decree of the Council of People's Commissars of 1921, while for a repeat offense they were taken to court

${ }^{2}$ Decree of the All-Russian Central Executive Committee 'O Revolutionary Military Railway Tribunals' of March 18, 1920 . Available ${ }^{3}$ Decree of the Council of People's Commissars 'On the Liability for Violating the Decree on Selling Grape, Fruit-Berry and Raisin
Vines' of October 7, 1921: Decree of the Council of People's Vines' of October 7, 1921; Decree of the Council of People'
Commissars 'On Administrative Penalties' of 1921 . Available at https://wfi. lomasm.ru/ pyсский.декреты_cсср_1917-1992. (асcessed 20.10.2019) 
Декретом Совета Народных Комиссаров о 14 декабря 1921 г. «Об ответственности заведующих государственными кооперативами частными предприятиями за уклонение от дачи в установленные сроки сведений, требуемых центральными и местными учреждениями» было закреплено, что за впервые совершенное нарушение лица карались дисциплинарным взысканием, а во второй раз - лишением свободы по суду.

В Уголовном кодексе РСФСР 1922 года также были закреплены положения о повторности. Так, в соответствии со статьей 118 , непредставление должностными лицами в срок по требованию центральных или местных властей необходимых сведений, справок, отчетов и т. п. каралось в первый раз в дисциплинарном порядке; во второй раз - принудительными работами на срок не менее трех месяцев с увольнением от должности. Статьей 79 этого же закона было предусмотрено, что неплатеж отдельными гражданами в срок или отказ от платежа налогов, денежных или натуральных, от выполнения повинностей или производства работ, имеющих общегосударственное значение, карался в первый раз административными взысканиями, налагаемыми соответствующими органами власти в пределах, законом определенных, а за повторный и упорный неплатеж или отказ от исполнения работ или повинностей или иные действия, устанавливающие злостность неплательшиков, - лишением свободы или принудительными работами на срок не менее шести месяцев или конфискацией всего или части имущества, или наложением имущественных взысканий не менее двойного размера тех же платежей или повинностей.

В Уголовном кодексе РСФСР 1926 года $^{3}$ согласно статье 162 , было предусмотрено дисциплинарно-преюдициальное применение наказаний, а именно за кражу материалов и орудий, совершенную на фабрике и заводе рабо-

Сборник документов по истории уголовного законодательства СССР и РСФСР 1917-1952. М.: Госюриздат, 1963. С. 106.

Уголовный кодекс РСФСР 1922 г. URL http://law.edu.ru/norm/norm.asp?normID=1241523\&subID= ще $26269,100096272,100096338,100096411$ \#ехе (дата обра-
щения: 10.06.2019). ${ }^{3}$ Уголовный кодекс РСФСР 1926 г. (с изм. и доп., внесенными постановлениями ЦИК
Собр. законов. 1926. № 9, ст. 71 . чим или служащим в пределах своего предприятия в первый раз и при стоимости похишеннодисциплинарное взыскание, а во второй раз уголовное наказание. В этот период уже зарождалась практика применения административнопреюдициальных норм. Статья 192 данного Закона устанавливала наказание в виде предупреждения или принудительных работ на срок до одного месяца или штраф до ста рублей, налагаемые в административном порядке, за нарушение обязательных постановлений местных органов власти, издаваемых ими в пределах установленной законом компетенции, а равно постановлений, приказов и инструкций отдельных ведомств, издаваемых по уполномочиям законодательных органов, если в них специально оговорено право на установление административных взысканий. Также в статье 612 УК РСФСР 1926 года было предусмотрено: за отказ от выполнения повинностей или производства работ, имеющих общегосударственное значение, лицо подвергалось административному взысканию, а за повторные действия назначались принудительные работы в судебном порядке. Однако при принятии Уголовного коекса РФ 1996 года законодатель на время отказался от использования административнопреюдициальных норм. В соответствии со статьей 18 данного Закона, было закреплено понятие рецидива преступлений, под которым признавалось совершение умышленного преступления лицом, имеющим судимость за ранее совершенное деяние. Рецидив преступлений, в зависимости от степени тяжести совершенного преступления, классифицируется на два вида: опасный и особо опасный. Важным предопределяюшим юридически значимым критерием для определения факта рецидива является совершение преступления по признаку повторности, если ранее лицо было привлечено к ответственности в количестве двух и более раз за преступления соответствуюшей степени тяюести, что влечет применение более строгого наказания.

Вместе с тем усиление карательной функции в виде назначения более строгого наказания распространилось и на повторно совершаемые административные проступки. Фактически можно вести речь о том, что история становления и развития законодательства об ад-
Decree of the Council of People's Commissars of December 14, 1921 'On Liability of the Directors of State Cooperatives and Private Companies for Evasion of Providing in Time the Inforation Requested by Central and Local Authorities ${ }^{11}$ ran that the first offense is punishable by disciplinary action and the second offense is punishable by imprisonment through court proceedings.

The RSFSR Criminal Code of $1922^{2}$ also contained regulations on repetition. In particular, according to Article 118 (failure of the officials to provide in due time necessary data, statements, reports etc. requested by the central or local authorities), the first offense was punishable by a disciplinary action; the second offense was punishable by correctional labor during at least three month and dismissal from work. Article 79 of the same law ran that failure of certain individuals to pay taxes in due time, or their refusal to pay taxes, whether in cash or in kind, the refusal to perform labor duties or perform works which were of nationwide importance, were punishable for the first time by an administrative sanction imposed by the espective authorities within the limits defined by law, and for the second or persistent failure to pay or refusal to perform labor duties or any other actions indicating the evil intention of the nonpayers, the individual was punished with imprisonment or correctional labor for at least six months, or with full or partial forfeiture of property, or with pecuniary sanctions in the amount equal to or more than the size of the above payments or labor duties.

Article 162 of the RSFSR Criminal Code of $1926^{3}$ prescribed disciplinary-prejudicial application of punishments; in particular, theft of mateCollection of Documents on the History of Criminal Law of ${ }^{2}$ Criminal Code of the RSFSR of 1922. Available a http://law.edu.ru/norm/norm.asp?normID=1241523\&subID= 96269,10009272,100096338,100096411\#text (accessed 20.10.2019)

Criminal Code of the RSFSR of 1926 (as amended and supof the USSR of February 19, 1926). Collection of Laws. 1926. No. 9. Art. 71 rials and tools committed at a factory/plant by a worker on the territory of his company for the first time, in case the cost of the stolen items did not exceed fifteen robles, carried disciplinary punishment, and repeat theft carried criminal punishment. In this period, the practice of applying administrative-prejudicial norms was emerging. Article 192 of this law established such punishment as issuing a warning or a fine in the amount of up to one hundred robles, both imposed in administrative proceedings, for violating the mandatory resolutions of the local authorities issued by them within the limits of their competence prescribed by law, as well as the resolutions, orders and instructions of certain agencies issued by them under the authorization of legislative bodies in case the authorization expressly provided for the right to impose administrative penalties. Moreover, Article 612 of the RSFSR Criminal Code of 1926 established that for the refusal to perform labor duties or works of a nationwide importance, the individual was to be punished administratively, and the repeat offense was punishable by corrective labor imposed through judicial procedures. However, when adopting the RF Criminal Code of 1996, the legislator temporarily abandoned the idea of using administrative-prejudicial norms. Article 18 of this law introduced the concept of repetition of offenses, which was understood as commitment of an offense by a person who had a criminal record for a previously committed offense. Depending on the gravity of the committed crime, repetition of of fenses is divided into two types: dangerous and especially dangerous. An important predetermining and juridically meaningful aspect for establishing the fact of recidivism is commitment of the offense by repetition, when the person has previously been held liable for crimes of similar gravity two or more times; this carries a more severe punishment.

At the same time, reinforcement of the punitive function, expressed in awarding a more severe punishment, also extended over repeat administrative offenses. It can be said that the history of legislation on administrative liability, 
министративной ответственности также свидетельствует о наличии признаков рецидива в виде повторности совершаемых административных проступков. Например, практика применения повторности в 1940-х годах свидетельствует о том, что за нарушение правил, установленных для учета военнообязанных рядового и младшего начальствующего состава, совершенное в первий раз, эти военнообязан соподвергались штрафу до 50 рублей, налагаемому в административном порядке начальниками отделений милиции или председателями сельских или поселковых Советов. За нарушение правил, установленных для учета военнообязанных начальствующего состава, совершенное в первый раз, эти военнообязанные подвергаются штрафу до 100 рублей, налагаемому в административном порядке районными или городскими военными комиссарами. Также было предусмотрено усиление карательной функции за повторно совершенное правонарушение зависимости от категории субъекта административной ответственности. Так, если повторно нарушение правил воинского учета было совершено лицами рядового или младшего начальствующего состава, то оно влекло за собой наказание в виде принудительных работ на срок до одного месяца или штраф до 200 рублей. А если подобные нарушения совершались лицами начальствующего состава, то применялись принудительные работы на срок до двух месяцев или штраф до 400 рублей. При этом было закреплено, что штраф и принудительные работы за повторное нарушение правил воинского учета назначались только в судебном порядке

Фактически до 1980 года для законодаельства нашей страны, регулируюшего порядок привлечения к административной ответственности, было характерно отсутствие единого кодифицированного закона и многообразие нормативно-правовых актов, которые, наряду с ооложениями о государственном контроте и надзоре ${ }^{2}$, содержали нормы об административ-

Об ответственности за нарушение правил воинского учета: указ Президиума Верхов. Совета СССР от 30 июл O

$O$ праве Народного комиссариата водного транспорта нарушение взыскания в административном порялке: по становление ЦИК и СНК СССР от 3 мая 1931 г. // Собр. законов СССР. 1931. № 26, ст. 207. ной ответственности за отдельные виды нарушений и о применении взысканий в администтивные взыскания устанавливались только за те нарушения, которые не содержали признако преступлений, преследуемых в судебном порядке. При этом размеры штрафов, налагаемых в административном порядке, варьировались зависимости от того, кто наделялся правом решать вопрос о привлечении к ответственности. Так, например, в 1929 году народным комиссариатам труда союзных республик предоставлялось право издавать обязательные постановления по вопросам найма рабочей силы, охраны труда и социального страхования с установлением административных взысканий за их нарушение. В качестве взыскания, налагаемого в административном порядке, был предусмотрен штраф в пределах не свыше 100 рублей. При этом штрафы в размере до 25 рублей налагались инспекторами труда, а в пределах от 25 рублей до 100 рублей - губернскими, окружными или соответствующими им органам труда ${ }^{3}$. Далеко не во всех случаях можно было вести речь о возможности применения в судебном порядке более строгого наказания за аналогичное деяние, но у же в соответствии с уголовным законодательством. Так, например, в уголовном законодательстве 1929 года не было предусмотрено составов, которые бы устанавливали ответственность за нарушение правил о труде, связанных с наймом рабочей силы, охраной труда или социальным страхованием. В более поздний период, начиная с 40-х годов до 1980 года, в некоторых нормативных актах, предусматривающих порядок привлечения к административной ответственности за отдельные виды нарушений, содержались некоторые положения о возможности применения боле строгого наказания в административном порядке за повторно совершенное деяние. В некоторых случаях, для того чтобы признать деяние рых сорным, нужно было виявить такой признак, как совершение грубого нарушения, например, в сфере нарушений правил рыболовства и охраны рыбных запасов, за которые предусматривалась возможность наложения повы-

о мероприятиях по борьбе с нарушениями законодаот 2 янв. 1929 г. // Там же. 1929. № 4, ст. 31. its establishment and development also speaks to the signs of recidivism in the form of repetition of committed administrative offenses. For example, the practice of applying repetition in the 1940 hows that for the first violation of the rules established for keeping the record of soldiers and junio officers bound to military service, these individual bound to military service incurred a fine of up to 50 rubles imposed in administrative proceeding by the heads of the militia (police) departments or by the chairmen of the village/rural council. For the first violation of the rules established for keeping the record of senior officers bound to military service, these individuals bound to military service incurred a fine of up to 100 rubles imposed in administrative proceedings by the district/ town military commissars. Reinforcement of the punitive function for the repeat offense also depended on the category of the administratively liable person. In particular, if the repeat violation of the rules on keeping the records of military service was committed by soldiers or junior officers, it carried punishment in the form of corrective labor for period of up to one month or a fine in the amoun of up to 200 rubles. In case the offenses were committed by senior offices, there was applied corrective labor for the period of up to two months, or fine in the amount of up to 400 rubles. It was established that the fine and corrective labor for the repeat violation of the military records rules could only be imposed by court

Until 1980, our country's legislation on regulating the procedure of holding administratively liable lacked a single codified law; there was a variety of legal acts which contained norms on adinistrative liability for certain types of offenses and on the imposition of administrative punishments, along with the provisions on government control and supervision ${ }^{2}$. As a rule, administrative

Decree of the Presidium of the Supreme Soviet of the USS On the Liability for Violating the Rules of Military Registrition' of July $30,1940$. B
USSR. 1940 . No. 28.

of People's Deputies of the USSR 'On the Authority of the eople's Commissariat for Water Transport to Issue Mandato- punishments were only imposed for offenses which did not contain the signs of a crime subject to the court hearing. The amount of fine imposed in administrative procedure varied depending on who was entitled to take the decision on whether to hold the individual liable or not. For example, in 1929 the People's Commissariats for Labor of the union republics were given the right to issue mandatory regulations on employment, labor safety and socia insurance, and prescribe the types of administrative punishment for violation thereof. The administrative punishment involved a fine in the amount of not more than one hundred rubles. Fines which did not exceed 25 rubles were imposed by labor inspectors, while those exceeding 25 rubles and no exceeding 100 rubles - by regional, territorial or equivalent executive labor bodies ${ }^{3}$. It was not in every case that a more severe punishment for a similar offense could be applied through the court proceedings, though under criminal law. In particuar, criminal legislation of 1929 did not provide for the elements of offense which would have established a liability for violating the labor rules associated with employment, labor safety or social insurance. Later, from the 1940s through 1980, some of the normative acts which established the procedure for applying administrative punishment for certain types of offense contained a number of regulations on the possibility to apply a more sever administrative punishment for a repeat offense. In some cases, for recognizing the offense as a repeat one, it was required to identify the offense as being gross; for example, this referred to violating the

Resolutions and Impose Administrative Liability for Viol Th Thereof of May 3, 1931. Collection of Laws of the USS

'Decree of the Central Executive Committee and the Council of People's Deputies of the USSR 'On the Measures Agains
Violations of the Labor Legislation' of January 2, 1929. Col lection of Laws of the USSR. 1929. No. 4. Art. 31 
шенных размеров штрафа ${ }^{1}$. Применение повторности прослеживалось и в том случае, когда за отдельные виды нарушений денежный штраф мог быть назначен, если меры дисциплинарного взыскания и общественного воздействия оказывались на практике недостаточнь ми, например, за нарушения санитарно-гигиенических и санитарно-противоэпидемических правил планировки и застройки населенных мест, охраны атмосферного воздуха, поверхностных и подземных вод, почвы, норм радиационной безопасности, проектирования, строительства, реконструкции, эксплуатации и содержания жилых домов и других объектов ${ }^{2}$.

В дальнейшем понятие повторности было закреплено в «Основах законодательства Союза ССР и союзных республик об административных правонарушениях», принятых Верховны Советом ССР 23 октября 1980 г. ${ }^{3}$ и регулирующих только процессуальные вопросы осуществления производства по делам об административных правонарушениях, не закрепляя составы административных правонарушений. Повторность совершенного административного правонарушения было отнесено к числу обстоятельств, отягчающих административную ответственность. Повторным признавалось совершение однородного правонарушения, за которое лицо уже подвергалось административному взысканию. При этом ужесточение административного взыскания было предусмотрено также в отношении лица, которое ранее совершило преступление. Данное отягчающее административную ответственность обстоятельств применялось в период действия срока, когда лицо считалось подвергнутым административному взысканию, т. е. в течение года со дня окончания его исполнения (ст. 21 Основ)

Наряду с этим отдельными указами Президиума Верховного Совета СССР устанавливалась административная ответственность за отдельные виды нарушений. Например, ука-

' Инструкиия о действиях инспекторов рыбоохраны при выявлении нарушений и задержании нарушителей Прави рыболовства и охраны рыб̆ых запасов: утв. приказом
Миньбхоза СССР от 30 нояб. 1979 г. № 91 ПГ. О государственном санитарном надзоре в СССР: постаСовмина СССР от 29 окт. 1963 г. № 1107 Собр. постан

${ }^{3}$ Основы законодательства Союза ССР и союзных республлик об административных правонарушениях // Ведомости ВС СССР. 1980. № 44, ст. 909. зом Президиума Верховного Совета СССР от 15 марта 1983 г. «Об административной ответственности за нарушение правил дорожного движения» ${ }^{4}$ уже было предусмотрено назначение более строгих размеров штрафов или лишение права управления транспортным средст вом за участие в групповом передвижении или создание аварийной ситуации на дорогах, угрозы безопасности при движении на дорогах городах и населенных пунктах, если эти нарушения по своему характеру не влекли за собой уголовную ответственность.

В 1984 году с принятием Кодекса РСФСР об административных правонарушения ${ }^{5}$ произошла кодификация процессуальных и материальных норм об административной ответственности. Заложенное в Основах понятие повторности полностью сохранило свое юридическое содержание в КоАП РСФСР в качестве обстоятельства, отягчающего административную ответственность (ч. 1 п. 2 ст. 35 КоАП РСФСР)

Анализ закрепленных в КоАП РСФСР составов административных правонарушений позволяет сделать вывод о том, что повторность была заложена и в структуре норм в качестве самостоятельного квалифицирующего признака, когда в санкции уже предусматривалас возможность назначить более строгое наказание. Однако подход законодателя по правилам исчисления годового срока при определении повторно совершенного проступка не единообразный.

Например, за административные правонарушения на транспорте и в области дорожног движения с формулировкой «те же действия совериенные повторно в течение года» было предусмотрено назначение более строгого взыскания в виде лишения права управления транспортным средством в качестве альтернативы увеличенному по размеру административному штрафу. В некоторых случаях формулировка квалифицирующего признака повторности в составе нарушения была закреплена как «те же действия, совершенные повторно в течение года после наложения администра-

${ }^{4}$ Об административной ответственности за нарушения правил дорожного движения: указ Президиума Верхов. Совет СССР от 15 марта 1983 г.: утв. Законом СССР от 17 ию ${ }^{5}$ Колекс РСФСР об алминистративных право ях: утв. ВС РСФСР 20.06.1984 // Ведомости ВС РСФСР 1984. № 27 , ст. 909 . rules in the sphere of fishery and fish stock protec tion resulting in the possibility to impose heavie fines $^{1}$. Repetition was also applied in cases when certain types of offenses could carry penalties if disciplinary punishment and community sanction turned to be insufficient in practice. These, for example, included cases of breaking the sanitaryhygienic and sanitary-antiepidemic rules of planning and building in populated areas; protection of atmospheric air, surface and subsurface waters, soil, radiation safety; design, construction, reconstruction and usage of residential buildings and other objects ${ }^{2}$.

Later, the concept of repetition was set in the 'Fundamental Principles of Legislation of the Union of SSR and Union Republics on Administrative Offenses' adopted by the Supreme Soviet on October $23,1980,{ }^{3}$ which only regulated procedura aspects of administrative proceedings and did no define the elements of administrative offenses. Repetition of the committed administrative offense was classified as an aggravating circumstance in liability. The repeat offense was defined as an of fense for which the individual had already been hold liable. A more severe administrative punishment was also established for an individual who had earlier committed a crime. This circumstance aggravating administrative liability was applied in the period when the individual was considered to be held liable, i.e. within a year from the completion of the punishment execution (Article 21 of the Fundamental Principles).

With this, separate Decrees of the Presidium of the Supreme Soviet of the USSR established administrative liability for some types of viola-

'Guidance on Operating Procedures for Fish Guarding In' the Order of Ministry of Fish Industry of the USSR No. 91/P of November 30, 1979

Decree of the Council of Ministers of the USSR No. 1107 'On the State Sanitary Control in the USSR' of October 29 1963. Collection of Decrees of the Council of Ministers of the (25). 1963. No. 20. Art. 199

Socialist Rentablics and the Union Republics on Administe tive Offenses. Bulletin of the Supreme Soviet of the USSR. 1980. No. 44. Art. 909. tions. For example, Decree of the Praesidium of the USSR Supreme Soviet 'On Administrative Liability for Traffic Offense ${ }^{4}$ of March 15, 1983 provided for more severe fines or for the driving license suspension for participation in vehicle driving in groups, or for driving which causes acciden conditions on the road, safety risks on the road in cities and populated localities in case these of fenses do not create criminal liability by their nature.

In 1984, when the Administrative Offense Code of the RSFSR (hereinafter - RSFSR AOC) was adopted, the procedural and substantial norm on administrative liability were codified. The concept of repetition, which had been put into the Fundamental Principles, fully preserved its juridical content in the RSFSR AOC as a circumstance aggravating administrative liability (Part 1 of Item 2 of Art. 35 of the RSFSR AOC).

The analysis of the offense elements enshrined in the RSFSR AOC allows for a conclusio that repetition was also embedded in the structure of the norms as an independent qualifying criterion in those cases when the sanction provided for a more severe punishment. However, the legislator's approach to the rules of calculating the one-year period when identifying a repeat offense is not consistent.

For example, administrative offenses in transport and in the sphere of road traffic defined as 'the same actions performed repeatedly during one year' were punishable more severely with the driving license suspension as opposed to the alternative of a heavier administrative fine. In some cases, the wording of the qualifying criterion of the offense element was settled as 'the same actions perfor med repeatedly within a year after imposition of

Decree of the Presidium of the Supreme Soviet of the USSR 'On Administrative Liability for Traffic Offense' of March 15, 1983: approved by the USSR Law of June 17, 1983. Bulleti Administrative Offense Code of the RSFSR (approved by Supreme Soviet of the RSFSR on 20.06.1984). Bulletin of the Supreme Soviet of the RSFSR. 1984. No. 27. Art. 909. 
тивного взыскания», что существенным образом отличалось от установленного правила применения отягч ror год должен был исчисляться со дня исполнения, а не после наложения взыскания. Подобным образом характеризовались и составы административных правонарушений в области торговли и финансов, за совершение которых санкциях был предусмотрен увеличенный размер штрафа с конфискацией валюты, платежных документов либо с обязательным приостановлением действия специального разрешения (лицензии) или его аннулированием. За административные правонарушения, посягающие на общественный порядок, квалифицирующий признак повторности был закреплен как «mе же действия, совершенные повторно в тече ние года после применения мер административного взыскания». В данном случае также возникает вопрос: является ли тождественной такая формулировка «после применения мер административного взыскания» правилу исчисления срока, когда лицо считается подвергну тым административному взысканию в течение года со дня его исполнения? Применение административного взыскания - это его наложение или исполнение?

Вместе с тем интересен подход законодателя к конструкции состава административного правонарушения статьи 162 КоАП РСФСР, которая предусматривала ответственность за распитие спиртных напитков в общественных местах или за появление в общественных местах в пьяном виде. Так, если за впервые совершенное деяние нарушителю могло быть назначено предупреждение или минимальный размер штрафа, то за повторно совершенный проступок его действия квалифицировались уже по части второй данной статьи закона с усиленной штрафной санкцией без альтернативного права назначения предупреждения. В ситуации, когда «ли ио дважды в течение года подвергалось административноиу взисканиюе за распитие спиртных напитков в общественных местах или за появление в общественных местах в пьяном виде, его действия уже квалифицировались по части 3 статьи 162 КоАП РСФСР, в санкции которой было предусмотрено не только наложение большего размера штрафа, но и альтернативный вариант в виде исправительных работ с удержанием процентов заработка.
В исключительных случаях, если по обстоятельствам дела и с учетом личности нарушителя применение этих мер признавалось недостаточным, мог быть назначен административный арест на срок до пятнадцати суток. При квалификации деяния за занятие проституцией по признаку повторности действия должны были быть совершены 8 течение года после наложения административного взыскания, а санкция предусматривала увеличенный в два раза размер административного штрафа. По такому же принципу законодатель усилил наказание за повторное приставание к иностранным гражданам с целью приобретения вещей, дополнив санкцию безальтернативным взысканием в виде конфискации этих вещей.

Аналогичным образом было закреплено несколько «повторных» составов административных правонарушений, посягающих на установленный порядок управления. Заметим, что только в некоторых составах административных правонарушений, совершенных в сфере установленного порядка управления, содержится формулировка повторности применительно к периоду «подвергнутости» административному взысканию, т. е. ответственност наступает за «те же действия, совершенные лицом, которое в течение года было подвергнуто административному взысканию за одно из нарушений, предусмотренных частью первой настоящей статьи». Примером такой конструкции составов могут быть обозначены только два случая: нарушение порядка приобретения, хранения, передачи или продажи гражданами огнестрельного гладкоствольного охотничьего оружия (ст. 172 КоАП РСФСР); нарушение правил хранения или перевозки огнестрельного оружия и боевых припасов (ст. 173 КоАП РСФСР)

Если учесть, что в КоАП РСФСР было закреплено 292 статьи, которыми устанавливалась административная ответственность за нарушения в различных сферах обшественных отношений, то только в 17 случаях составь включали повторность в качестве квалифицирующего признака. Анализируя данные составы административных правонарушений, можно сказать, что выборочный подход законодателя к этому вопросу свидетельствует о степени общественной значимости и вредности совершаемого проступка, но не все из них содержали administrative punishment'. This significantly differed from the established rule of applying the ag gravating circumstance, when the year should be calculated from the date of the punishment execution but not the punishment imposition. The elements of trade and financial offenses were characterized in the same way, and the sanctions provided for a heavier fine with confiscation of currency, or with mandatory suspension of special permission (license) or its withdrawal. For administrative offenses against the public order, the qualifying criterion of repetition was defined as the same actions performed repeatedly within a year after applying the measures of administrative punishment.' In this case, there arises a question: is the wording 'after applying the administrative punishment measures' identical to the rule of calculating the period when the person is considered to be administratively punished within a year after the punishment was executed? Is applying an administrative punishment actually its imposition or execution?

Noteworthy is the legislator's approach to the construction of the elements of the administrative offense as per Article 162 of the RSFSR AOC which covered the liability for drinking alcohol in public places or being drunk in public places. A warning or minimum fine could be imposed on the offender for the first offense, while the repeat of fense actions were qualified in accordance with part 2 of the above article with heavier fine sanctions and no alternative right to get a warning again. In a situation when 'an individual was penalized with administrative punishment twice within a year' for drinking alcohol or being drunk in public places, his actions were qualified as per part 3 of Article 162 of the RSFSR AOC, whose sanction prescribed not only a heavier fine but also an alternative in the form of corrective labor and deduction of a part of the salary.
In exceptional cases, when, according to the facts of the case and the personality of the offender, this punishment was recognized as insufficient, the administrative arrest could be applied for a period of up to 15 days. For the offense of prostitution to be qualified as repeated, the actions should have been performed within a year after imposing administrative punishment, and the sanction prescribed a twofold administrative fine. The sam principle was used by the legislator when stiffening punishment for the repeat harassment of foreign citizens for the purpose of purchasing goods, and the sanction was complemented with such punishment as confiscation of these goods, with no alternative.

Several other 'repeat' elements of administrative offenses impinging upon the established administrative procedures were enshrined in a similar way. Let us note that only some of the elements of administrative offenses committed in the sphere of the established administrative procedures contain the definition of repetition as applied to the period of 'being subjected' to administrative punishment, i.e. the liability incurs for 'the same actions performed within one year by the individual who had incurred administrative punishment for one of the violations stipulated by part 1 of this article There are only two examples of the above construction of the elements: violating the procedure for purchasing, handling, transfer and sale of firing smooth-bore hunting weapons to the citizens (Article 172 of the RSFSR AOC) and violating the rules of storage and transportation of fire arms and ammunition (Article 173 of the RSFSR AOC).

The RSFSR AOC contained 292 articles which established administrative liability for violations in different spheres of social relations. However, repetition as the qualifying criterion of the elements of offense was contained only in 17 of them. Analyzing these elements of administrative offenses, one can say that the legislator's selective approach to this task indicates the degree of the public significance and harmfulness of the committed offense, but not all of them contained the 
умышленную форму вины. Если сравнить критерии отнесения к рецидиву совершаемых уголовно-наказуемых деяний, то речь в основном идет о повторно совершенном умышленном преступлении.

\section{Юридическое значение повторности}

совершения административного правонарушения в современных условиях

В современной правоприменительной практике органов исполнительной власти и судов вопрос о повторности совершенного административного проступка продолжает быть весьма значимым и актуальным. Интересно то, что в ныне действующем КоАП РФ заложень базовые положения о повторности совершенного проступка, которые были закреплены еще в 1980 г. в Основах законодательства об административных правонарушениях, а затем, в 1984 году, и в КоАП РСФСР.

Наряду с этим в КоАП РФ содержательное значение слова «повторность» несет в себе многогранную смысловую нагрузку и понимается как:

1) обстоятельство, отягчающее административную ответственность;

2) самостоятельный квалифицирующий признак состава административного правонарушения;

3) критерий для квалификации деяния в качестве грубого административного нарушения;

4) административно-преюдициальное основание для квалификации деяния в качеств уголовно-наказуемого преступления.

Рассмотрим особенности правового регу лирования и практики применения каждого из названных аспектов.

\section{Повторность - как обстоятельство}

отягчающее административную ответственность

Повторность совершения административного правонарушения является обстоятельством, отягчающим административную ответственность, и имеет важное значение для применения правил назначения административных наказаний (ч.1 п. 2 ст. 4.3 КоАП РФ).

При применении повторности в качестве отягчающего обстоятельства ключевыми моментами являются: период действия срока «подвергнутости» административному наказанию и однородность совершенного проступка.

Срок действия, в течение которого лицо считается подвергнутым административному наказанию, исчисляется со дня вступления постановления по делу об административном правонарушении в законную силу и длится в течение одного года со дня окончания исполнения административного наказания (ст. 4.6 КоАП РФ). В предыдущей редакции, до 2013 г. ${ }^{1}$, данный срок исчислялся только со дня исполнения административного наказания, что на практике не позволяло применить отягчающее обстоятельство в том случае, когда наказание оказывалось неисполненным и производство по делу прекращалось за истечением сроков давности. В современной редакции правило исчисления данного срока работает немного по-иному. Так, например, если в отношении гр. Н. было вынесено постановление о назначении административного наказания в виде штрафа 1 сентября 2019 г., которое вступило в законную силу с 11 сентября 2019 г., а 10 декабря 2019 г. административный штраф был взыскан судебными приставами-исполнителями, то в период с 11 сентября 2019 г. по 10 декабря 2020 г. при назначении наказания за совершение нового проступка данное положение подлежит применению в качестве отягчающего обстоятельства.

Вновь совершенное правонарушение будет считаться повторным при условии отнесения его к категории однородного по отношению к ранее совершенному деянию. Однако признаки однородности административного правонарушения в КоАП РФ не закреплены.

Согласно разъяснениям Пленума Верховного Суда РФ, «однородным считается правонарушение, имеющее единый родовой объект посягательства, независимо от того, установлена ли административная ответственность

Новые положения об исчислении срока, в течение которого лицо считается подвергнутым административному наказанию, были включены в ст.4.6 КоАП РФ Федеральным законом «О внесении изменений в Кодекс Россий-

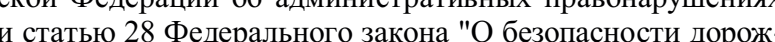
ного движения"» от 23 июля 2013 г. № 196-Ф3 // Собр. законодательства Рос. Федерации. 2013. № 30, ч. ст. 4029

Telegin A. S., Tiunova N. V.

intentional form of guilt. If we compare the criteria of classifying criminal offenses as cases of recidivism, we will see that in most cases this refers to the repeat intentional crime.

\section{Repetition of Administrative Offenses and Its} Juridical Meaning in Modern Conditions

In the modern law enforcement practice of the executive power bodies and courts, the question of repeat administrative offenses continues to be rather important. An interesting fact is that the Administration Offense Code currently in force in the Russian Federation contains the fundamental principles of the administrative offense repetition, which were originally settled as far back as in 1980 in the Fundamental Principles of the Legislation on Administrative Offenses, and then in 1984 - in the RSFSR AOC.

The scope of the term 'repetition' in the RF AOC has a multifaceted meaning and is understood as:

1) a circumstance aggravating administrative liability;

2) an independent qualifying criterion of the elements of the administrative offense;

3) a criterion for qualifying the offense as a gross administrative violation;

4) an administrative-prejudicial ground for qualifying the action as a criminally punishable offense.

Let us study the details of the legal regulation and practice of applying each of the mentioned aspects.

Repetition as a Circumstance Aggravating Administrative Liability

Repetition of administrative offenses is a circumstance aggravating administrative liability and it has an important meaning for the application of rules of the administrative punishment imposition (part 1 of Item 2 of Article 4.3 of the RF AOC).

When applying repetition as an aggravating circumstance, the key aspects are: the period of 'being subjected to' administrative punishment and the similarity in nature of the committed offense.

The period for which an individual is considered to be administratively penalized begins on the day when the decision on the administrative offense case enters into force and continues for one year after the execution of the administrative punishment (Article 4.6 of the RF AOC). In the previous version, which was in effect until $2013^{1}$, this period began on the day of the administrative punishment execution, which did not allow applying an aggravating circumstance in practice in those cases when the punishment turned to be not executed and the proceedings on the case were closed because the limitation period had expired. In the current version, the rule of calculating the period works in a slightly different way. For example, if on September 1, 2019 there was a court decision on the imposition of a fine, the decision came into legal effect on September 11, 2019, and on December 10, 2019 the fine was collected by the enforcement officers, then, in case of imposing penalty for a new offense in the period from September 11, 2019 to December 10, 2019, this would be applied as an aggravating circumstance.

The new offense will be recognized as a repeat offense in case its nature is similar to that of the previously committed offense. However, the criteria of the similarity of nature are not defined in the RF AOC.

According to the explanation of the RF Supreme Court, 'the offense of similar nature is the offense having the same generic object of offense regardless of whether or not administrative liability

The new provisions on calculating the period for which the person is considered to be administratively penalized were included into Article 4.6 of the Administrative Offense Code of the Russian Federation by Federal Law No. 196-FZ 'On sian Federation and Article 28 of Federal Law 'On of the Rusfic Safety' of July 23, 2013. Collection of Legislative Acts of the Russian Federation. 29.07.2013. No. 30 (Part I) Art. 4029. 
за совершенные правонарушения в одной или нескольких статьях КоАП РФ».

Рассмотрим особенности практики применения судебного толкования вопроса об однородности административных правонарушений.

Если составы административных правонарушений предусмотрены разными статьями и включены законодателем в одну главу Особенной части КоАП РФ по одному родовому признаку (например, гл. 12 КоАП РФ - нарушения в области правил дорожного движения), то автоматически их можно отнести к категории однородных деяний.

Но проблема в том, что некоторые глав Особенной части КоАП РФ предусматривают множественность видов родовых объектов. Например, глава 6 объединяет составы нарушений, отнесенных к трем видам родовых объектов (здоровье, санитарно-эпидемиологическое благополучие населения и общественная нравственность). В главе 15 КоАП РФ предусмотрено четыре вида родовых объектов посягательств (область финансов, налогов и сборов, страхования, рынка ценных бумаг и др.). Определить однородность составов административных правонарушений в подобных случаях весьма проблематично, поскольку законодатель не регламентировал и не разграничил составы нарушений внутри главы с указанием на конкретный родовой объект посягательств. Представляется, что вопрос о включении составов административных правонарушений в одну главу Особенной части КоАП РФ должен решаться законодателем исключительно по одному виду родового объекта, исключая какуюлибо их множественность. Это позволит упростить процедуру отнесения состава административного правонарушения к категории однородного ранее совершенного проступка

В то же время если административная ответственность за вновь совершенное правонарушение предусмотрена одной и той же статьей либо разными частями в пределах одной статьи Особенной части КоАП РФ, то с позиции судебного толкования деяние также признается однородным и, соответственно, должно приме-

$O$ некоторых вопросах, возникающих у судов при притивных правонарушениях: постановление Пленума Верхов. Суда РФ от 24 марта 2005 г. № 5 (ред. от 19.12.2013) Бюл. Верхов. Суда РФ. 2005. № 6. няться правило отягчающего обстоятельства при назначении административного наказания. При этом к категории однородных относятся гакже составы административных правонарушений, которые предусматривают повторност в качестве самостоятельного квалифицирующего признака за аналогичное деяние

Представляется, что признаки однородного административного правонарушения, обозначенные Пленумом Верховного Суда РФ, должны быть закреплены непосредственно в статье 2.1 КоАП РФ, которая регламентирует понятие административного правонарушения. Также в часть 1 пункта 2 статьи 4.3 КоАП РФ необходимо в понятие однородного деяния включить понятие аналогичного административного правонарушения.

Правило отягчающего обстоятельства при привлечении к административной ответственности за повторно совершенное однородное деяние на практике может носить номинальный характер и фактически не работать. Это обусловлено двумя факторами.

Во-первых, в КоАП РФ до сих пор предусмотрены нормы с безальтернативными санкииями, которые не позволяют выбрать боле строгое административное наказание по виду или размеру относительно того, что было назначено ранее. Речь также идет об отсутствии верхних и нижних пределов штрафных санкций. Например, административный штраф в размере 500 рублей (ч. 2 ст. 12.9 и ч. 2 ст. 12.14 КоАП РФ), 1 тыс. рублей (ч. 1 ст. 12.30 КоАП РФ) или 3 тыс. рублей с конфискацией (ч. ст. 12.4 КоАП РФ), 20 тыс. рублей в отношении должностных лиц и в размере 100 тыс. рублей (ст. 12.32 КоАП РФ) в отношении юридических лиц и др.

Во-вторых, в главе 4 КоАП РФ, которая регламентирует правила назначения административных наказаний, не предусмотрено возможности назначить более строгое наказание за пределами санкции при совершении повторнооднородного правонарушения.

По общему правилу, административное наказание назначается в пределах, установленных законом, в том числе в пределах санкции соответствующей статьи Особенной части КоАП РФ либо Закона субъекта РФ об административных правонарушениях (ч. 1 ст. 4.1 КоАП РФ). is established for committed offenses under one or several articles of the RF AOC'

Let us study the practice of juridical interpretation for similar nature of administrative offenses.

If the elements of administrative offenses are provided for by different articles and are included by the legislator into the Special Part of the RF $\mathrm{AOC}$ according to one generic characteristic (for example, Chapter 12 of the RF AOC - offenses against traffic regulations), then they can automatically be referred to offenses of similar nature.

The problem is that some chapters of the Special Part of the RF AOC provide for the multiplicity of the types of generic objects. For example, Chapter 6 covers the elements of offenses which refer to three types of generic objects (health, sanitary-epidemiological welfare of the population and public morals). Chapter 15 of the RF AOC provides for four types of objects of offense (sphere of finances, taxes and duties, insurance, securities market) and others. In these cases, it is rather difficult to determine the similarity of nature of the offenses, as the legislator does nor regulate and differentiate between the offense elements within the chapter and does not indicate the specific generic object of the offense. Seemingly, the question of including all the elements of the administrative offense into one chapter of the Special Part of the RF AOC should be solved by the legislator exceptionally for each type of the generic object eliminating any multiplicity thereof. This will allow simplifying the procedure of classifying the elements of the administrative offense as similar to the previous offense.

In those cases when administrative liability for a subsequent offense is covered by the same article or by different parts of the same article in the Special Part of the RF AOC, from the position of judicial interpretation, the offense is also classi-

${ }^{1}$ Resolution of the Plenum of the Supreme Court of the Russian Federation No. 5 'On Certain Questions Raised by the Russian Federation' of March 24, 2005 (as amended on 19.12.2013). Bulletin of the Supreme Court of the Russion Federation. 2005. No. 6. fied as having a similar nature, and correspondingly the aggravating circumstance rule should be applied when awarding the punishment. Those elements of offense which provide for repetition as an independent qualifying criterion for an analogous offense also refer to the category of offenses similar in nature.

Seemingly, the characteristics of a similar nature administrative offense identified by the RF Supreme Court Plenum should be enshrined directly in Article 2.1. of the RF AOC, which regulate the concept of administrative offense. Moreover, it is necessary to include the notion of similar offense in part 1 of Item 2 of Article 4.3 of the RF AOC.

The aggravating circumstance rule used for imposing administrative liability in practice can be of a nominal character and may not actually work. This is explained by two factors

Firstly, the RF AOC still does not contain norms with non-alternative sanctions which do not allow choosing a more severe administrative punishment in terms of its type/size as compared to the previously awarded punishment. There are also no upper and lower limits of fine sanctions. For example, the administrative fine in the amount of 500 rubles (part 2 of Article 12.9. and part 2 of Article 12.14. of the RF AOC), 1,000 rubles (part of Article 12.30 of the RF AOC) or 3,000 rubles with confiscation (part 1 of Article 12.4 of the RF AOC), 20,000 rubles for officials and 100,000 rubles for legal persons (Article 12.32 of the RF AOC) and others.

Secondly, Chapter 4 of the RF AOC, which regulates the rules of awarding administrative punishments, does not provide for an opportunity to award a more severe punishment beyond the sanction limits for a repeat similar offense.

According to the general rule, administrative punishment is awarded within the limits prescribed by law, including the limits of the sanction established in the corresponding article of the Special Part of the RF AOC or the RF territorial entity's law on administrative offenses (part 1 of Article 4.1 of the RF AOC). 
За впервые совершенное административное правонарушение может быть назначено наказание в виде предупреждения при отсутствии угрозы возникновения вреда или причинения имущественного ущерба (ст. 3.4 , ч. 3.5 ст. 4.1 КоАП РФ). Например, когда в санкции содержится альтернатива выбора наказания в виде предупреждения или административного штрафа за нарушение, предусмотренное частью 1 статьи 12.17 КоАП РФ. В том случае, когда данный вид наказания не предусмотрен санкцией, оно не применяется. Исключением из этого правила являются субъекты малого и среднего предпринимательства, которым за впервые совершенные деяния штраф може быть заменен предупреждением за пределами санкции (ст. 4.1.1 КоАП РФ). В исключительных случаях административный штраф может быть назначен в меньшем размере, чем предусмотрено в санкции. Например, вполовину меньше установленной нижней границей санкции (ч. 3.1-3.3 ст. 4.1 КоАП РФ) либо в размере одной трети от размера административного штрафа (ч.2, 4 и 6 ст. 14.5 КоАП РФ), за нарушение правил применения контрольнокассовой техники (ч. 3.4.ст. 4.1 КоАП РФ).

Кроме того, необходимо учитывать, что признание повторного совершения однородного правонарушения отягчающим обстоятельством является правом, а не обязанностью должностного лица, в производстве которого находится дело на рассмотрении (ч. 1 ст. 4.3 КоАП РФт).

Изучение решений судов, в которых отражаются сведения о принятии во внимание наличие либо отсутствие отягчающего обстоятельства в виде повторности совершения однородного административного правонарушения, позволяет вести речь о многообразии вариантов должностного усмотрения.

Суды учитывают отсутствие повторности и назначают административный штраф в минимальном размере. Например, арбитражному управляющему было назначено административное наказание в виде штрафа в минимальном пределе санкции на основании части 3 статьи 14.13 КоАП РФ с мотивировкой отсутствия повторности ${ }^{1}$. Однако в санкции этой статьи

предусмотрено альтернативное наказание в в де предупреждения, а ответственность за повторное аналогичное деяние в качестве ка фицирующего признака установлена в части 3.1 статьи 14.13 КоАП РФ.

Весьма проблематичными являются применение правила отягчающего обстоятельства и назначение более строгого наказания, когда одновременно выявляется несколько фактов однородных или аналогичных нарушений, совершенных одним и тем же лицом. При применении правила отягчающего обстоятельства в виде повторности за однородное нарушение, так же как и в случае квалификации по признаку повторности за аналогичное деяние, необходимо учитывать срок, предусмотренный статьей 4.6 КоАП РФ применительно к вступлению в законную силу постановления о назначении наказания за предыдущее нарушение

Заметим, что однородность при определении повторности как отягчающего обстоятельства является наследием 80-х годов, т. е. тех времен, когда в Основах законодательства об административных правонарушениях еще не было предусмотрено сложных составов правонарушений с самостоятельным квалифицирующим признаком в виде повторности за аналогичное деяние. Однако их появление в КоАП РФ существенным образом изменило практику применения правила отягчающего обстоятельства. Фактически применение повторности в качестве отягчающего обстоятельства за совершение однородного проступка, предусмотренного одной и той же статьей, утрачивае свою актуальность и не может быть применено, если повторность является квалифицирующим признаком состава нарушения с более строгой санкцией.

Если на законодательном уровне сохранять юридическое значение повторности в качеств отягчающего обстоятельства, то необходимо пересмотреть содержательную часть санкций, включить в каждую из них альтернативный вариант назначения административного наказания либо предусмотреть алгоритм выбора административного наказания, назначаемого за первое, второе и последующее однородное правонарушение.

ный ресурс]. Доступ из справ.-правовой системы «КонсультантПлюс».
The first administrative offense can be punished with a warning, should there be no risk of harm or damage to property (Article 3.4., part 3.5. of Article 4.1. of the RF AOC). For example, when a sanction contains a choice between a warning or an administrative fine for an offense covered in part 1 of Article 12.17. of the RF AOC. In those cases when the type of punishment is not prescribed by the sanction, punishment is not applied. The exceptions from this rule are small and medium-sized business entities for which the fine can be replaced with a warning beyond the limits of the sanction (Article 4.1.1 of the RF AOC). In exceptional cases, an administrative fine can be awarded in the amount less than that provided for by the sanction. For example, one half as much as the lower limit of the sanction (parts 3.1.-3.3. of $\mathrm{Ar}-$ ticle 4.1. of the RF AOC) or one third of the administrative fine provided for in parts 2, 4 and 6 of Article 14.5. of the RF AOC for violating the rules of using cash register equipment.

Moreover, it is necessary to keep in mind that viewing a repeat similar offense as an aggravating circumstance is the right and not the obligation of the official responsible for studying the case (part 1 of Article 4.3 of the RF AOC).

The examination of judicial decisions which contain information on the presence or absence of the aggravating circumstance in the form of repetition of a similar administrative offense demonstrate the multiformity of the official discretion variants.

The courts take into account the absence of repetition, and award administrative fines at a minimum. For example, a bankruptcy commissioner was awarded with an administrative punishment in the form of a fine in the minimum limit of the sanction in accordance with part 3 of Article 14.13. of the RF AOC, and the reasoning of punishmen included the absence of repetition ${ }^{1}$. However, the

${ }^{1}$ Decision of the Supreme Court of the Russian Federation
No 305 -ES 19-7650 of June 10, 2019 on case No. A40101621/2018. Available at: http///www.consultant.ru/ (accessed 20.10.2019). sanctions of this article provide for an alternative punishment in the form of a warning, and the liability for a repeat similar offense as a qualifying criterion is set by part 3.1. of Article 14.13 of the RF AOC.

Applying the aggravating circumstance and awarding a more severe punishment is rather problematic in cases when several facts of committing similar or analogous offenses by the same person are revealed. When the aggravating circumstance in the form of repetition is applied, as well as when the analogous offense is qualified as per the repetition criterion, it is necessary to consider the term provided for by the RF AOC Article 4.6, which establishes the effective date of the judicial decision on the imposition of punishment for the previous offense.

Let us note that similarity as an aggravating circumstance in establishing the fact of repetition is the legacy of the 1980s, i.e. of those days when the Fundamental Principles of the Legislation on Administrative Offenses did not contain complicated elements of offenses with the independent qualifying criterion of repetition for an analogous offense. However, introduction of the above elements into the RF AOC significantly changed the practice of applying the aggravating circumstance. In fact, application of repetition as an aggravating circumstance for committing a similar offense covered in the same article, is no longer of relevance and cannot be applied if repetition is a qualifying criterion of the elements of offense with a more severe sanction.

If the juridical meaning of repetition as an aggravating circumstance has to be preserved legislatively, it is necessary to revise the contents of sanctions and complement each of them with an alternative variant or awarding an administrative punishment, or to provide for an algorithm of selecting the administrative punishment awarded for the first, second and every subsequent similar offense. 
Представляется, что алгоритм процессуальных действий должностных лиц должен быть максимально упорядочен и регламентирован. Для этого в статье 4.1 КоАП РФ целесообразно предусмотреть следующие правила назначения административных наказаний при наличии отягчающего обстоятельства в виде повторно совершенного правонарушения:

- за впервые совершенное административное правонарушение назначается наказание в виде предупреждения вне зависимости от того, предусмотрено оно в санкции соответствующей статьи или нет;

за повторно совершенное однородное административное правонарушение, предусмотренное одной статьей, частями одной или другой статьи Особенной части КоАП РФ либо Закона субъекта РФ об административных правонарушениях, объединенных одним родовым признаком объекта посягательств, адиинистративное наказание назначается в пределах санкции;

- за дважды повторно совершенное административное правонарушение административное наказание назначается в двукратно размере либо в сроке от верхних пределов, предусмотренных в санкции статьи;

за многократное (три и более раз) повторно совершенное административное правонарушение, административное наказание назначается в трех- и более кратном размере либо в сроке от верхних пределов, предусмотренных в санкции статьи.

Альтернативой данному предложению может быть замена безальтернативных санкций альтернативными, которые позволяли бы дифференцировать вариант выбора административного наказания при его назначении и применении отягчающего либо смягчающего ответственность обстоятельства. В качестве еще одного из вариантов на дальнейшую перспективу можно предложить отнесение к исключительной компетенции судов рассмотрение дел об административных правонарушениях, совершенных повторно.

Это во многом упорядочит правоприменительную практику, которая позволит реализовать в полном объеме механизм последовательного усиления адинистративных наказий и возродить принцип неотвратимости наказа
при систематическом рецидиве проступков.
Повторность - как самостоятельный
квалифищирующий признак состава

алминистративного правонарушения

Законодатель во многих случаях закрепи. повторность в качестве самостоятельного квалифицирующего признака состава административного правонарушения, за совершение которых предусмотрел возможность назначения более строгого административного наказания На протяжении последних лет прослеживается тенденция к увеличению таких составов. В настоящее время от общего количества составов административных правонарушений, закрепленных в КоАП РФ, с квалифицирующим признаком повторности предусмотрено 108 составов. Фактически каждый десятый состав предусматривает повторность в качестве квалифицирующего признака.

Анализ правоприменительной практики части повторности в качестве квалифицирующего признака состава административного правонарушения позволяет вести речь о следующих важных и значимых аспектах.

Bo-nервых, для квалификации обязательно совершение аналогичного правонарушения, предусмотренного конкретной статьей. В КоАП РФ понятие «аналогичного» административного правонарушения не закреплено. Однако в практике судебного толкования № 5 , на примере части 2 статьи 5.27 КоАП РФ, Пленум Верховного Суда РФ разъяснил, что под аналогичным правонарушением следует понимать совершение такого же, а не любого нарушения (например, первый раз должностное лицо не произвело расчет при увольнении одного, а позднее - при увольнении другого работника).

Bo-вторыx, при квалификации деяния в качестве повторного наказание назначается в пределах предусмотренной санкции и повторность в качестве отягчающего обстоятельства не применяется (ч. 2 ст. 4.3 КоАП РФ).

Если гражданин совершает неоднократно аналогичные правонарушения, за которые он ранее уже привлекался к ответственности ка за повторное деяние, а санкция статьи за данное нарушение предусмотрена безальтернативная, то в каждом последующем случае усиление карательной функции со стороны государства уже не предусмотрено. Например, частью 7 статьи 12.9 КоАП РФ предусмотрено наказа-
Seemingly, the algorithm of the officials' procedural actions should be rectified and regulated to the greatest possible extent. For this, it is practicable to include the following rules of awarding administrative punishment involving an aggravating circumstance into Article 4.1 of the RF AOC:

the first administrative offense should be punishable with a warning irrespective of whether or not this punishment is specified in sanction of the corresponding article;

for a repeat similar administrative offense covered by one article, by parts of one or anothe article of the Special Part of the RF AOC or of the Law on administrative offenses of a constituen entity of the Russian Federation, providing that they have a common generic characteristic of the object of the offense, administrative punishment is awarded within the limits of the sanction;

- for an administrative offense repeatedly committed twice, administrative punishment is awarded at twice the size or the term of the uppe punishment limit set forth in the sanction of the article;

for multiple (three and more times) repea administrative offense, administrative punishmen is awarded at thrice the size or the term of the upper punishment limit set forth in the sanction of the article.

As an alternative to this proposal, nonalternative sanctions can be replaced with alternative ones, which would allow for differentiating between the choice of the administrative punishment when awarding the punishment and applying the circumstance that aggravates or mitigates liability. Placing the repeat administrative offense cases under the exclusive jurisdiction of the court can be one more option proposed for future considerations.

This would considerably streamline the law enforcement practice, which would allow implementing the mechanism of the successive reinforcement of administrative punishments to the full extent and also restoring the principle of inevitability of punishment in case of systematic recidivism.

\section{Repetition as an Independent Qualifying}

Criterion of the Administrative Offense

Elements

In many cases, the legislator established repetition as an independent qualifying criterion of the elements of the administrative offense, with a more severe punishment for it. In the last few years, there has been observed a tendency to increasing these elements. Currently the total number of elements covered by the RF AOC includes 108 elements with the qualifying criterion of repetition, that is one in ten elements has repetition as a qualifying criterion.

The analysis of the law enforcement practice of applying repetition as a qualifying criterion of an administrative offense allows us to highlight the following important aspects:

Firstly, the qualification requires commitment of an analogous offense set forth in a certain article. The RF AOC does not give a definition of an 'analogous' offense. However, in the judicial interpretation practice, the RF Supreme Court Plenum explained though the example of part 2 of Article 5.27 of the RF AOC that an analogous offense should be understood as committing the same offense but not any type of offense (for example, an official did not pay all amounts due to one leaving employee and later did not pay the same to another leaving employee).

Secondly, when an offense is qualified as repeat, punishment is awarded within the limits of the prescribed sanction and repetition as an aggravating circumstance is not applied (part 2 of Article 4.3 of the RF AOC).

When an offender commits multiple analogous offenses for which he was previously held liable as for repeat offenses, and if the sanction of the article is non-alternative, then for every subsequent offense there is not provided any further aggravation of penalty. For example, part 7 of Article 12.9 of the RF AOC provides for a penalty in the form 
ние в виде административного штрафа в размеpe 5 тыс. рублей за повторное превышение установленной скорости движения, зафиксированное работающими в автоматическом режиме специальными техническими средствами Если в период срока, предусмотренного статьей 4.6 КоАП РФ, нарушитель совершит впоследствии еще одно или несколько повторных аналогичных нарушений, то каким образом можно будет применить к нему правило отягчающего обстоятельства и назначить более строгое наказание? К сожалению, в подобных ситуациях данное правило не может в полной мере быть реализовано на практике. В данном случае размеры административного штрафа должны быт вариативными - от минимального до максимального предела либо санкция должна предоставлять возможность должностному лицу назначить более строгий вид административного наказания. На практике также возникае проблема, связанная с назначением административного наказания в виде лишения прав управления транспортным средством в том случае, если физическое лицо повторно совершает аналогичное деяние. Как справедливо отмечает М. Н. Кобзарь-Фролова, в данных случаях возникают правовые противоречия части статьи 3.8 КоАП РФ и части 2 статьи 32.6 КоАП РФ [2, с. 500]. С одной стороны, невозможно лишить прав того, кому это право уже не предоставлено. С другой стороны, невозможно исполнить наказание в виде лишения специального права путем изъятия водительского удостоверения, поскольку оно уже изьято на период исполнения ранее назначенного административного наказания. Этот пример также свидетельствует о том, что необходимо выработать новый подход к наполнению санкций в плане их вариативности.

В качестве альтернативного варианта совершенствования КоАП РФ можно было бы предложить вернуться к ранее существовавшей схеме последовательного выбора более строгого наказания при совершении второго и третьего проступков в период срока административной наказанности. В качестве примера можно привести статью 162 КоАП РСФСР 1984 г., согласно которой за распитие спиртных напитков в общественных местах или появление в общественных местах в пьяном виде, совершенное впервые, в качестве взыскания предусматрива- лось предупреждение или минимальный штраф. За повторное деяние - более высокий размер шитрафа. उа дажды совершенное - еше более высокий размер штрафа либо исправительные работы на срок от одного до двух месяцев с удержанием двадцати процентов заработка. Кроме того, в исключительных случаях, если по обстоятельствам дела и с учетом личности нарушителя применение этих мер признавалось недостаточным, мог быть назначен административный арест на срок до пятнадцати суток.

$B$-третьих, при квалификации деяния качестве повторного, а также когда повторность может применяться в качестве отягчающего обстоятельства, должен учитываться один и тот же срок, предусмотренный статьей 4.6 КоАП РФ. В этой связи во многих материалах дел об административных правонарушениях при квалификации деяния в качестве повторного содержится указание и на наличие отягчающего обстоятельства - повторности. В некоторых случаях срок, указанный в статье 4.6 КоАП РФ, не принимается во внимание при квалификации деяния ${ }^{1}$. Так, суды одновременно назначают наказания за первое и второе нарушения, квалифицируя второе в качестве повторного, при отсутствии факта вступления в законную силу постановления о назначении административного наказания за первое деяние с нарушением сроков, предусмотренных статьей 4.6 КоАП РФ.

Например, решением Арбитражного суда Удмуртской Республики от 24 ноября 2017 г. по делу А71-9149/2017 арбитражный управляющий был одновременно привлечен к административной ответственности по двум составам нарушений в виде наложения штрафа в размере 40000 руб. (ч. 3 ст. 14.13 КоАП РФ) и дисквалификации на срок шесть месяцев, квалифицируя деяние по признаку повторности однородного проступка (ч. 3.1 ст. 14.13 КоАП РФ) $)^{2}$. Решением Арбитражного суда Нижегородской области от 10 июня 2016 г. арбитражному управляюшему назначено наказание по части 3 статьи 14.13 КоАП РФ в виде штрафа в размере 50000 руб. и, одновременно, по час-

${ }^{1}$ Постановление Верховного Суда РФ от 13.03.2019 г № 18-АД19-12 [Электронный ресурс]. Доступ из справправовой системы «КонсультантПлюс».

Постановление Арбитражного суда Уральского округа
от 20.06.2018 г. № Ф09-2935/18 по делу № А71-9149/2017 [Электронный ресурс]. Доступ из справ.-правовой систе мы «КонсультантПлюс». of a fine of 5 thousand rubles for repeat driving over the prescribed speed limits, which is recorded automatically with special technical means. If during the period established by Article 4.6 of the RF AOC, the offender commits one or more repeat analogous offenses, then how can the aggravating circumstance rule be applied against him and how can be a more severe punishment imposed? Unfortunately, in such situations the above rule canno be fully implemented in practice. In this case, the size of the administrative fine should vary from the minimum to the maximum level, or the sanction should give the official an opportunity to apply a more severe type of administrative punishment. In reality, there occurs a problem with awarding administrative punishment in the form of the driving license suspension for a repeat analogous offense committed by the person. As M.N. Kobzar-Frolova was right to say, such cases cause legal contradictions between part 1 of Article 3.8 of the RF AOC and part 2 of Article 32.5 of the RF AOC [2, p. 500]. On the one hand, it is not possible to deprive a person of the right which he has been already deprived of. On the other hand, it is not possible to execute punishment in the form of deprivation of the right through forfeiture of the driving license as it has already been forfeited for the period of the previous punishment execution. This example also indicates the necessity to develop a new approach to the content of sanctions in terms of their variability.

As an alternative option of improving the RF AOC, one could suggest going back to the previously applied scheme of successive choice of more severe punishment for the second and third offenses committed during the period of the firs administrative punishment imposition. An example of this can be found in Article 162 of the RSFSR AOC of 1984, which ran that drinking alcohol or being drunk in public places for the first time, wa punishable by a warning or a minimum fine. A repeat offense carried a heavier fine. Two repea offenses were punishable with corrective labor during one to two months and a $20 \%$ salary deduction.
In addition, in exceptional situations, when the circumstances of the case and the personality of the offender made these measures insufficient, the person could have been administratively arrested for a period of up to 15 days.

Thirdly, when an offense is qualified as repeat, and in those cases when repetition can be applied as an aggravating circumstance, the same time period provided for by Article 4.6 of the RF AOC should be considered. For this reason, in many administrative case files, when an offense is qualified as repeat, there is also a reference to the presence of repetition as an aggravating circumstance. In some cases, the time period indicated in Article 4.6 of the RF AOC is not taken into consideration while qualifying the offense ${ }^{1}$. In particular, the courts award punishments simultaneously for the first offense and the second offense qualifying the latter as repeat if the decision on awarding punishment for the first offense has not come into effect, thus disregarding the period provided for by Article 4.6 of the RF AOC. For example, according to the decision of the Arbitrazh Court of the Udmurt Republic of November 24, 2017 in case No. A71-9149/2017, an insolvency administrato was simultaneously hold administratively liable fo two elements of offense, in the form of a fine in the amount of 40,000 rubles (part 3 of Article 14.13 of the RF AOC) and disqualification from administrating for the period of two months, based on the criterion of repetition of a similar-nature offens (part 3.1 of Article 14.13 of the RF AOC) $)^{2}$. According to the decision of the Arbitrazh Court of the Nizhny Novgorod region of June 10, 2016, an insolvency administrator was awarded with punishment as per part 3 of Article 14.13 of the $\mathrm{R}$ AOC in the form of a fine in the amount of 50,000 rubles and simultaneously - with disqualification

${ }^{1}$ Resolution of the Supreme Court of the Russian Federation
No. 18-AD19-12 of March 13, 2019. Available at: No. 18-AD19-12 of March 13, 2019. Av
http://www.consultant.ru/ (accessed 20.10.2019). ${ }^{2}$ Resolution of the Arbitrazh Court of the Ural Circuit Resolution of the Arbitrazh Court of the Ural Circuit No
F09-2935/18 of June 20, 2018 on case No. A71-9149/2017. Available
$20.102019)$ at: http://www.consultant.ru/ (accessed 
ти 3.1 статьи 14.13 КоАП РФ в виде дисквалификации на три года ${ }^{1}$. Вышестоящей судебной инстанцией это решение суда было отменено в части привлечения к административной ответственности за повторное деяние и производство по делу прекращено, а размер штрафа, по части 3 статьи 14.13 КоАП РФ, снижен до 25000 тыс. рублей

В том и другом примере нарушения были выявлены органом власти одновременно, по каждому из них в один день были составлень протоколы об административных правонарушениях. И при отсутствии факта привлечения к административной ответственности за первое деяние, действия за второе были квалифицированы по части 3.1 статьи 14.13 КоАП РФ, которая предусматривает в качестве самостоятельного квалифицирующего признака повторность. Поскольку за первое нарушение период предусмотренный статьей 4.6 КоАП РФ, еще не наступил, то действия арбитражного управляющего подлежат квалификации без признака повторности и ему должны быть назначень наказания за каждое нарушение в отдельности либо с применением правила назначения наказания при совершении нескольких нарушений, предусмотренных статьей 4.4 КоАП РФ. Учигывая, что, по части 3 статьи 14.13 КоАП РФ, в санкции предусмотрено с альтернативой выбора наказание в виде предупреждения или штрафа, то вопрос о том, какое из них будет назначено, решается в каждом случае с учетом должностного усмотрения.

Для упорядочения и систематизации норм КоАП РФ, регулирующих правила назначения административных наказаний за повторные правонарушения, представляется необходимым: во-первых, заменить в КоАП РФ безальтернативные санкции на альтернативные; вовторых, в каждом составе административного правонарушения предусмотреть соответствующую часть, которая бы включала квалифицируюший признак - повторное совершение административного правонарушения.

Определение Верховного Суда РФ от 20.04.2017 № 301-АД17-3039 по делу № А43-5260/2016 г. ГЭлектронный ресурс]. Доступ из справ.-правовой системы «КонсультантПлюс)

'Постановление Первого арбитражного апелляционного ронный ресурс]. Доступ из справ.-правовой систем «КонсультантПлюс».
Пов торность - как один из критериев

для квалификации деяния в качестве

Тенденции современного законодательств об административных правонарушениях свидетельствуют о том, что грубое деяние включено в качестве самостоятельного квалифицирующего признака некоторых составов. Однако юридическое содержание понятия грубого нарушения характеризуется многообразием толкования. Например, в большинстве случаев для определения грубого нарушения законодатель определил такой критерий, как нарушение, приведшее к возникновению непосредственной угрозы жизни или здоровью людей и окружающей среде (примечание к ч. 3 ст. 9.6 КоАП РФ), либо иные последствия, предусмотренные Правительством Российской Федерации (примечание к ч. 7 ст. 13.12 КоАП РФ), ${ }^{3}$ или отдельными федеральными законами (ч. 2 ст. 18.13 КоАП РФ) $)^{4}$. В некоторых случаях законодатель установил административную ответственность за грубое нарушение, если действия не содержат уголовно наказуемого деяния (ч. 2 ст. 20.8 КоАП РФ). Таким образом, законодатель предусмотрел свыше тридцати составов административных правонарушений.

Наряду с этим в качестве одного из критериев для определения понятия грубого нарушения в некоторых составах закреплено повторное совершение административного правонарушения. Так, в примечании к части 3 статьи 14.55 КоАП РФ (грубое нарушение условий

Об утверждении Положения о лицензировании деятельности по разработке, производству, распространению шифровальных (криптографических) средств, информационных систем и телекоммуникационных систем, защи-
щенных с использованием шифровальных (криптографических) средств, выполнению работ, оказанию услуг қиванию шифровальных (криптографических) средств, информационных систем и телекоммуникационных систем, защищенных с использованием шифровальных (криптографических) средств (за исключением случая, если техническое обслуживание шифровальных (криптокоммуникашионных систем, зашищенных с использованием шифровальных (криптографических) средств, осушествляется для обеспечения собственных нужд юридического лица или индивидуального предпринимателя): постановление Правительства РФ от 16 апр. 2012 г. № 313 (ред. от 18.05.2017) Со Собр. О лицензировании отдельных видов деятельности: Федер. закон от 4 мая 2011 г. № 99-Ф3 (ред. от 27.12.2018) Там же. 2011. № 19, ст. 2716.

Telegin A. S., Tiunova N. V.

of a fine of 5 thousand rubles for repeat driving over the prescribed speed limits, which is recorded automatically with special technical means. If during the period established by Article 4.6 of the RF AOC, the offender commits one or more repeat analogous offenses, then how can the aggravating circumstance rule be applied against him and how can be a more severe punishment imposed? Unfortunately, in such situations the above rule cannot be fully implemented in practice. In this case, the size of the administrative fine should vary from the minimum to the maximum level, or the sanction should give the official an opportunity to apply a more severe type of administrative punishment. In reality, there occurs a problem with awarding administrative punishment in the form of the driving license suspension for a repeat analogous offense committed by the person. As M.N. Kobzar-Frolova was right to say, such cases cause legal contradictions between part 1 of Article 3.8 of the RF AOC and part 2 of Article 32.5 of the RF AOC [2, p. 500]. On the one hand, it is not possible to deprive a person of the right which he has been already deprived of. On the other hand, it is not possible to execute punishment in the form of deprivation of the right through forfeiture of the driving licens as it has already been forfeited for the period of the previous punishment execution. This example also indicates the necessity to develop a new approach to the content of sanctions in terms of their variability.

As an alternative option of improving the RF AOC, one could suggest going back to the previously applied scheme of successive choice of more severe punishment for the second and third offenses committed during the period of the firs administrative punishment imposition. An example of this can be found in Article 162 of the RSFSR AOC of 1984, which ran that drinking alcohol or being drunk in public places for the first time, wa punishable by a warning or a minimum fine. A repeat offense carried a heavier fine. Two repeat offenses were punishable with corrective labor during one to two months and a $20 \%$ salary deduction.
In addition, in exceptional situations, when the circumstances of the case and the personality of the offender made these measures insufficient, the person could have been administratively arrested for a period of up to 15 days.

Thirdly, when an offense is qualified as repeat, and in those cases when repetition can be applied as an aggravating circumstance, the same time period provided for by Article 4.6 of the RF AOC should be considered. For this reason, in many administrative case files, when an offense is qualified as repeat, there is also a reference to the presence of repetition as an aggravating circumstance. In some cases, the time period indicated in Article 4.6 of the RF AOC is not taken into consideration while qualifying the offense $\mathrm{e}^{1}$. In particular, the courts award punishments simultaneously for the first offense and the second offense qualifying the latter as repeat if the decision on awarding punishment for the first offense has not come into effect, thus disregarding the period provided for by Article 4.6 of the RF AOC. For example, according to the decision of the Arbitrazh Court of the Udmurt Republic of November 24, 2017 in case No. A71-9149/2017, an insolvency administrato was simultaneously hold administratively liable for two elements of offense, in the form of a fine in the amount of 40,000 rubles (part 3 of Article 14.13 of the RF AOC) and disqualification from administrating for the period of two months, based on the criterion of repetition of a similar-nature offense (part 3.1 of Article 14.13 of the RF AOC) $)^{2}$. According to the decision of the Arbitrazh Court of the Nizhny Novgorod region of June 10, 2016, an insolvency administrator was awarded with punishment as per part 3 of Article 14.13 of the $\mathrm{R}$ AOC in the form of a fine in the amount of 50,000 rubles and simultaneously - with disqualification

${ }^{1}$ Resolution of the Supreme Court of the Russian Federation
No. 18-AD19-12 of March 13,2019. Available at: No. 18-AD19-12 of March 13, 2019. Av
http://www.consultant.ru/ (accessed 20.10.2019). ${ }^{2}$ Resolution of the Arbitrach Cout of the Ual Circuit $\mathrm{No}$ Resolution of the Arbitrazh Court of the Ural Circuit No
F09-2935/18 of June 20, 2018 on case No. A71-9149/2017. Available at: http://www.consultant.ru/ (accessed 20.10.2019). 
государственного контракта по государственному оборонному заказу) определено, что понятие грубого нарушения устанавливается Правительством Российской Федерации. Интересен вительством Российской Федерации. Интересен
тот факт, что постановлением Правительства РФ от 2 июня 2014 г. № 504 «Об установлении понятия грубого нарушения условий государственного контракта по государственному оборонному заказу» в понятие грубого нарушения включено три признака:

- повторное совершение административного правонарушения, предусмотренного частью 1 и частью 2 статьи 14.55 КоАП РФ;

нарушение условий государственного контракта, повлекшее ущерб Российской Федерации на сумму не менее 5 процентов (но не менее 5 млн руб.) цены государственного контракта;

- нарушение условий государственного контракта, повлекшее невыполнение установленного задания по государственному оборонному заказу.

Таким образом, видим, что повторность совершения административного правонарушения в данном случае выступает в качестве одного из квалифицируюших признаков при определении понятия грубого нарушения наряду с наступлением вредных последствий. В этой связи возникает вопрос: повторность в данном случае должна применяться как самостоятельный признак для привлечения к административной ответственности за грубое нарушение или в комплексе с другими критериями, установленными Правительством Российской Федерации? Очевидно, что на практике возможно многообразие вариантов.

Акцентируя здесь внимание на повторности, необходимо вести речь о том, что, по правилам статей 4.3 и 4.6 КоАП РФ, необходимо соблюдать требования по применению признака повторности в качестве обстоятельства, отягчающего административную ответственность. При квалификации деяния в качестве грубого нарушения нужно учитывать не только факты совершения административных правонарушений, предусмотренных частью 1 и частью 2 статьи 14.55 КоАП РФ, но и срок, когда лицо считается подвергнутым административному наказанию за предыдущие нарушения. Представляется, что для правоприменителя часть 3 статьи 14.55 КоАП РФ является слож- ным составом, требующим особого внимания при квалификации и сборе доказательственной базы.

Однако стоит обратить внимание на то, что в иных случаях законодатель разграничил административную ответственность за грубое и повторно совершенное деяние. Так, например, в части 1 статьи 15.11 КоАП РФ предусмотрена ответственность за грубое нарушение требований к бухгалтерскому учету, в том числе к бухгалтерской (финансовой) отчетности, а в части второй этой же статьи уже за повторное совершение административного правонарушения, предусмотренного частью первой. В данном случае повторность выступает в качестве самостоятельного квалифицирующего признака состава нарушения и одновременно является отягчающим обстоятельством при привлечении к административной ответственности за грубое нарушение.

В других случаях законодатель установил альтернативу при квалификации. Например, в части 2 статьи 19.6.1. КоАП РФ, согласно которой ответственность наступает за повторное совершение административного правонарушения либо за грубое нарушение требований законодательства о государственном контроле (надзоре). Подобным образом обстоят дела и при квалификации по части 2 и части 3 статьи 20.31 КоАП РФ (нарушение правил поведения зрителей при проведении официальных спортивных соревнований).

Анализ значения повторности при квалификации составов административных правонарушений, предусматривающих ответственность за грубое деяние, свидетельствует о многообразии законодательных подходов. Насколько это целесообразно? В данном случае представляется, что для оптимизации правоприменительной практики нужен систематизированный единый вариант подхода к законодательному определению понятия повторности, исключив многоплановость и вариативность его юридического значения. Также представляется необходимым в статье 14.55 КоАП РФ предусмотреть самостоятельный состав за повторное совершение административного правонарушения, исключив этот критерий из понятия грубого нарушения, который определен постановлением Правительства Российской Федерации. (gross violation of terms of the government contract on the government defense order) runs that the definition of gross violation shall be given by the Government of the Russian Federation. An interesting fact is that RF Government Resolution of 02.06.2014 No. 504 'On the Definition of the Gross Violation of the Terms of the Government Contract on Government Defense Order' provides for three criteria of the gross violation concept:

repeat commission of an administrative offense provided for by parts 1 and 2 of Article 14.55 of the RF AOC;

- violation of the terms of the government contract resulting in damage to the Russian Federation in the amount of not less than 5 percent of the government contract price (but not less than 5 million rubles);

- violation of the terms of the government contract resulting in failure to fulfil the agreed task within the government defense order

Thus, it appears that in this case repetition of the administrative offense is one of the qualifying criteria for defining the gross offense, along with harmful consequences. Within this context, there arises a question of whether in this case repetition is an independent criterion for holding administratively liable for a gross offense, or should it be ap plied in complex with other criteria established by the RF Government? Obviously, many variants are possible in practice.

Focusing on repetition in this case, we should note that, according to the rules of Article 4.3 an 4.6 of the RF AOC, it is necessary to observe the requirements on applying repetition as a circumstance which aggravates administrative liability When an offense is qualified as a gross offense, one should account not only for the facts of committing administrative offenses as per parts 1 and 2 of Article 14.55 of the RF AOC but also for the period within which the person is considered to be held liable for the previous offenses. Seemingly, part 3 of Article 14.55 of the RF AOC is a complex element for the legislator, and it requires special attention in qualification and gathering of the evidential basis.

However, attention should be given to the fact that in other cases the legislator differentiates between administrative liability for a gross offense and the same for a repeat offense. For example, part 1 of Article 15.11 of RF AOC provides for liability for a gross violation of requirements for accounting operations including accounting (financial) reporting; and part 2 of the same article provides for liability for repeating the administrative offense set forth in part 1. In this case repetition is an independent qualifying criterion of the element of the offense, and at the same time is an aggravating circumstance for holding administratively liable for a gross offense.

In other cases, the legislator establishes an alternative for qualification. For example - in part 2 of Article 19.6.1 of the RF AOC, which prescribes liability for a repeat administrative offense or for a gross violation of the legislative requirements concerning the government control (supervision). The same is true for qualifying an offense as per parts 2 and 3 of Article 20.31 of the RF AOC (violation of the rules of conduct for the audience at official sporting events).

The analysis of the meaning of repetition for qualifying the elements of administrative offenses carrying liability for a gross violation, demonstrates the variety of legislative approaches. To what extent is it feasible? In this case, it seems that the optimization of law enforcement needs a systematized single approach to the legislative definition of the 'repetition' concept, where its versatility and the variability of its juridical meaning are avoided. In addition, we deem it necessary to supplement Article 14.55 of the RF AOC with a separate element for committing a repeat administrative offense and exclude this criterion from the 'gross violation' concept defined in the Resolution of the Government of the Russian Federation. 


\section{Повторность - как административно-} преюдициальное основание

\section{для квалификации}

\section{уголовно наказуемого деяния}

Повторно совершенное административное правонарушение также может являться основанием для квалификации в качестве уголовнонаказуемого деяния. Речь идет об административно-преюдициальных нормах, содержащихс в КоАП РФ и УК РФ.

Вместе с тем весьма важным в практике применения положений КоАП РФ о повторности остается вопрос административно-преюдициального характера, когда за дважды совершенное административное правонарушение деяние подпадает под квалификацию в соответствии с УК РФ. Административно-преюдициальные нормы, содержащиеся в УК РФ, в качестве квалифицирующего признака состава преступления включают такие формулировки, как:

1) деяние, совершенное лицом, подвергнутым единожды административному наказанию (например, ст. 158.1 УК РФ - мелкое хищение совершенное лицом, ранее подвергнутым наказанию по ч. 2 ст. 7.27 КоАП РФ);

2) неоднократность при условии, что лицо ранее привлекалось к административной ответственности за аналогичное деяние два раза течение одного года (например, ст. 19.24 КоАП РФ - несоблюдение административных ограничений и невыполнение обязанностей, устанавливаемых при административном надзоре и ст. 314.1. УК РФ - уклонение от административного надзора или неоднократное несоблюдение установленных судом в соответствии с федеральным законом ограничений).

Говоря о повторности совершения административного правонарушения, нужно отметить что ныне применяемые составы КоАП РФ и УК РФ свидетельствуют о расширении сферы действия административной преюдиции и криминализации административных правонарушений, когда признак повторно совершенного административного правонарушения является основанием для квалификации уголовно наказуемого деяния.

Заметим, что вопросу о юридическом смысле повторности совершения административных правонарушений, а также о целесооб- разности внедрения в уголовное законодательство России административно-преюдищиальных норм посвянено много трудов ученых, в каждом из которых определена своя научноисследовательская позиция

Одни считают не допустимым внедрение административно-преюдициальных норм в уголовное законодательство России [5, с. 68], другие поддерживают позицию законодателя [4, c. 179-186]. Третьи анализируют современную c. 179-186]. Третьи анализируют современную
терминологию при определении понятия повторности совершения административного правонарушения в действующем законодательстве Российской Федерации, дискутируя о повторности как о неоднократности, систематическом совершении однородного или аналогичного деяния, за которое лицо уже подвергалось административному наказанию [1, с. 82-88]. Сущность вопроса, по мнению М. Я. Масленникова, в том, что «в таких случаях правонарушитель завуалированно дважды подвергается административному наказанию за совершение первого административного правонарушения» [3, с. 50] Справедливо отмечает Э. Л. Сидоренко, что непоследовательность в нормативном оформлении преюдиционных норм (норм, содержащих элемент административной преюдиции) ставит перед юридической практикой ряд сложных проблем, одной из которых является определение начального времени исчисления срока привлечения к административной ответственности. В судебной практике момент привлечения лица к административной ответственности связывается либо со временем вынесения соответствующего постановления, либо с моментом вступления его в юридическую силу [6, с. 128-130].

Впервые административно-преюдициальные нормы были введены в УК РСФСР в 1964 г.: «В случае систематических нарушений условно осужденным в течение испытательного срока общественного порядка, повлекших применение мер административного взыскания или общественного воздействия, суд по представлению органа внутренних дел, а в отношении несовершеннолетнего - также комиссии по делам несовершеннолетних при исполнительном комитете районного, городского районного в городе Совета народных депутатов

Уголовный кодекс РСФСР: утв. ВС РСФСР 27 окт,
1960 г. (ред. от 30.07.1996)// Ведомости ВС РСФСР. 1960. № 40, ст. 591. (Утратил силу с 1 января 1997 г.).
Repetition as the AdministrativePrejudicial Basis for Qualifying a Criminally Punishable Offense

A repeat administrative offense can also be the basis for qualifying it as a criminally punishable offense. What is meant here is the administrative-prejudicial norms contained in the RF AOC and Criminal Code of the Russian Federation.

At the same time, a rather important question in application of the RF AOC regulations is the question of the administrative-judicial character when twice committed administrative offense falls under qualification in accordance with the RF CC The administrative-prejudicial norms contained in the RF Criminal Code include the following as qualifying criterion of the elements of the offense:

1) an offense committed by an individual wh has previously once been held administratively liable (for example, Article 158.1 of the RF Criminal Code - theft committed by an individual who has previously been held liable as per part 2 of $\mathrm{Ar}$ ticle 7.27 of the RF AOC);

2) duplicity, provided that the individual has previously been held administratively liable for an analogous offense twice within one year (for ex ample, Article 19.24 of the RF AOC - failure to observe administrative limitations and failure to fulfil duties established as part of administrative supervision, and Article 314.1 of the RF Criminal Code - evasion from administrative supervision, or multiple failure to observe limitations prescribed by the court pursuant to the federal law).

It should be noted that the currently applied elements of offense of the RF AOC and the RF Criminal Code demonstrate expansion of the sphere of the administrative prejudice application, when the repeat administrative offense criterion becomes the basis for qualifying a criminally punishable offense.

There are numerous works devoted to the jumeaning of the administrative offenses repetition and to the feasibility of introducing admin- istrative-prejudicial norms into the criminal legislation of Russia; and each of the works demonstrates a specific research position

Some of the scientists consider it inadmissible to introduce administrative-prejudicial norms into the criminal legislation of Russia [5, p. 68], other support the legislator's position [4, pp. 179-186]. Still others analyze modern terminology used for the conceptual definition of repetition in the current legislation of the Russian Federation, and dispute about repetition as duplicity and systematic commitment of a similar-nature or analogous of fense for which the individual has already been held administratively liable [1, pp. 82-88]. In the opinion of M. Ya. Maslennikov, the fact of the matter is that 'in such cases, the offender is veiledly administratively punished twice for the commitment of the first administrative offense' [3, p. 50]. E. L Sidorenko is right to say that inconsistency in the regulatory settlement of prejudicia norms (norms that contain the element of adminisrative prejudice) sets a number of complex probems before the juridical practice. One of the problems is finding the starting point for calculating the eriod of holding administratively liable. In judicia practice, the moment of bringing a person to administrative liability is associated either with the time of issuing the corresponding order, or with the moment of its entering into legal force [6, pp. 128-130].

Administrative-prejudicial norms were firs introduced in the RSFSR Criminal Code ${ }^{1}$ in 1964 'In the event that a person under suspended senence repeatedly violates the public order during the probationary period, which entailed the application of measures of administrative punishment or public influence, the court (at the request of the law enforcement agency, and with regard to a juvenile - also at the request of the juvenile affairs commission of the executive committee of the regional, city or district Soviet of People's Deputies)

Criminal Code of the RSFSR (approved by the Suprem 30.07.1996). Bulletin of the Supreme Soviet of the RSFSR. 1960. No. 40. Art. 591. (repealed on January 1, 1997). 
может вынести определение об отмене условного осуждения и о направлении осужденного для отбывания наказания, назначенного приговором» (ст. 44 УК РСФСР). Аналогичные нормы применялись и при нарушении правил административного надзора в период отсрочки исполнения приговора (ст. 46.1 УК РСФСР) Вместе с тем в этот период времени прослеживался не только процесс криминализации составов административных правонарушений, за совершение которых были включены составы УК РСФСР, но и декриминализации. В качестве примера этого процесса можно привести положения статьи 50.1. УК РСФСР «Освобождение от уголовной ответственности с привлечением $\mathrm{K}$ административной ответственностиґ, которая предусматривала возможность освобождения от уголовной ответственности с привлечением к административной ответственности лишь по делам о преступлениях, за которые законом предусматривается наказание в виде лишения свободы на срок не свыше одного года либо более мягкое наказание.

В период действия УК РСФСР было закреплено немало составов преступлений, в которых одним из квалифицирующих признаков было указано либо на специфику субъекта как лица, ранее подвергавшегося административному взысканию ${ }^{1}$, либо за «совершенные после наложения административного взыскания за такие же нарушения» ${ }^{2}$, либо за преступление,

${ }^{1}$ См., например, ст. 133.1. УК РСФСР (Нарушение избирательного зак, сода ному взысканию) (введена Законом РСФСР от 16.10.1990 № 243-1): «Нарушение избирательного законодательсте (законодательства о референдуме), совершенное лицом, которое в течение года подвергалось административному взысканию за такие же нарушения, - наказывается лише-

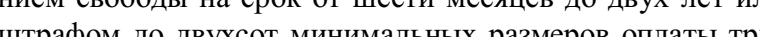
да» // Ведомости СНД РФ и ВС РФ. 1992. № 47, ст. 2664. ${ }_{2}^{2}$ См., например, ст. 133.2. УК РСФР (Нарушение законо-
дательства Российской Федерации о собраниях, митингах демонстрациях, шествиях и пикетированиях), котора была введена Федеральным законом от 18.07.1995 № $106-$ юлжностным лищом прелприятия или организани государственной торговли с использованием своего служебного положения после наложения на него административного взыскания за одно из этих нарушений. Таким же образом были предусмотрены административно-преюдиц. ст.162.1.РСФСР (Уклонение от подачи декларации о доходах), введена указом Президиума ВС РСФСР о
$28.05 .1986)$ // Ведомости ВС РСФСР. 1986. № 23, ст. 638 . «если оно совершено в течение года после наложения административного взыскания за таУК РФ алиинистративная преюдиция в составах преступлений утратила силу". Фактически олько с 2014 г. в УК РФ вновь стали вводиться административно-преюдициальные составы.

С увеличением количества парных составов административно-преюдициального харакгера значительно расширилась сфера законодательного подхода к определению понятия повторности. Вопрос о юридическом содержании повторности при квалификации деяний носит весьма разнообразный характер.

В некоторых случаях для квалификации деяния в качестве уголовно-наказуемого деяния достаточно ериночды быть привлеченным дминистративной ответств привле В пачестве примера можно привести часть 2 статьи 7.27 КоАП РФ (мелкое хищение) и статью 158.1 УК РФ (мелкое хищение, совершенное лицом, подвергнутым административному наказанию) В данном случае вопрос о привлечении к уголовной ответственности за повторное совершение административного правонарушения носит однократный характер. Так, при совершении мелкого хищения (ч. 2 ст. 7.27 КоАП РФ) во второй раз, действия нарушителя подлежа квалификации по статье 158.1 УК РФ.

Практика применения данных составов свидетельствует о том, что важным критерием для квалификации в качестве уголовно наказуемого деяния является период, равный одному году, в течение которого лицо считаетс подвергнутым административному наказанию. Этот срок исчисляется с момента вступления в законную силу постановления по делу об адмииистративном правонарушении. Если мелкое хищение на сумму, не превышающую две с по-

См., например, ст. 152.2. УК РСФСР (Необеспечение маркировки марками установленых образцов при производстве подакцизных товаров (введена Федеральным законом от 30 июля 1996 г. № 103-ФЗ), ст. 156. УК РСФСР отпуск бензина или дугих горюче - смазочных материа лов); ст. 162.4. УК РСФСР (Незаконное предпринимательство Осуществление предпринимательской деятельности без регистрации либо без специального разрешения (ли(Незаконное усын Федерации: Федер. закон от 13 июня 1996 г. № 64 -ФЗ (ред. от 13.07.2015) // Собр. законодательства Рос. Федерации. 1996. № 25, ст. 2955

Telegin A. S., Tiunova N. V.

may make a ruling as to cancelling the suspended sentence and sending the convicted person to serve punishment in accordance with the sentence' (Article 44 of the RSFSR Criminal Code). Simila measures were applied in case of violating the administrative supervision rules during the period of respite from the sentence execution (Article 46.1 of the RSFSR Criminal Code). Along with that, this period was characterized not only by the tendency of criminalization of the elements of administrative offenses which when committed were punishable as per the elements of the RSFSR Criminal Code, but also by the tendency of de-criminalization. The example of that can be found in the norms of Article 50.1 of the RSFSR Criminal Code 'Exemption from Criminal Liability and Punishment with Bringing to Administrative Liability', which provided for the possibility to exempt a person from criminal liability while holding him administratively liable, but solely for those cases which legislatively carry punishment in the form of imprisonment for the period of not more than one year or another less severe punishment.

During the validity period of the RSFSR Criminal Code, there were introduced many elements of offense which had the qualifying criteri either of the specific characteristic of the individual as of the person who has previously incurred administrative punishment ${ }^{1}$, or of 'offenses committed after administrative punishment for committing similar offenses was imposed ${ }^{2}$, or of the of-

See for example Article 133.1 of the Criminal Code of the the Referendum) by a Person Who Has Previously Been Penlized with Administrative Punishment) (introduced by Law of the RSFSR No. 243-1 of October 16, 1990): 'Violation of the legislation on election (legislation on the referendum) committed by person who in the course of one year was punished for simila from six months un to two years, or with a fine in the amount of in to two hundred minimum wages' Bulletin of the Congress People's Deputies of the Russian Federation and the Supreme Court of the Russian Federation. 1992. No. 47. Art. 2664. See for example Article 133.2 of the Criminal Code of the RSFSR (Violation of Legislation of the Russian Federation on ing; introduced by Federal Law No. 106-FZ of July 18, 1995): it established punishment for actions performed by an offici of the company or of the state trading organization with the abuse of his official position, after incurring administrative punishment for one of such offenses. In the same manner, 162 of the Criminal Code of the RSFSR (Engaging in Priohbited Practices of Individual Labor Activities), Article 162 of the Criminal Code of the RSFSR (Evasion of the Incone Declaration Submission), introduced by the Decree of the fense 'committed within one year after the imposition of administrative punishment for similar of fenses ${ }^{\text {'3 }}$. After the RF Criminal Code was adopted, administrative prejudice in the elements of offenses lost its effect ${ }^{4}$. In fact, the subsequent introduction of administrative-prejudicial elements into the RF Criminal Code did not begin until 2014

With the increase in the number of dual elements of the administrative-prejudicial character the sphere of the legislative approach to defining repetition has significantly expanded. The question of the legal content of repetition for qualifying offenses is viewed in different ways.

In some cases, for qualifying the offense as criminally punishable, it is necessary and sufficien for a person to be once held administratively liable The examples of that can be found in the following elements: part 2 of Article 7.27 of the RF AOC (theft) and Article 158.1 of the RF Criminal Code (a theft committed by an individual previously penalized for an administrative offense). In this case, imposition of criminal liability for a repeat administrative offense is possible only once. In particular, when a theft provided for by part 2 of Article 7.27 of the RF AOC is committed for the secon time, the offender's actions are subject to qualification as per Article 158.1 of the RF CC.

The practice in the application of these elements shows that an important criterion for qualifying an offense as criminally punishable is the period equal to one year during which the individual is considered to be subjected to administrative punishment. This period is calculated from the moment when the decision on the administrative offense case comes into legal force. If a theft with the damage amount not exceeding two and a half thousand rubles is committed for the second time the Supreme Soviet of the RSFSR. 1986. No. 23. Art. 638 . See for example Article 152.2 of the Criminal Code of the
RSFSR (Failure to Provide Standard Marking on Excisable Goods in Production) (introduced by Federal Law No. 103-FZ of July 30, 1996); Article 156 of the Criminal Code of the of the RSFSR (Illegal Sale of Petrol and Other Fuel and Lubrication Materials); Article 162.4 of the Criminal Code of the RSFSR (Illegal Entrepreneurship, Illegal Performance of Entrepreneurial Activities with no Registration or no Special Permission (License); Article 162.9 of the Criminal Code of the 4SFR (Illegal Adoption). Russian Gazette. 1995. March 15. inal Code of the Russian Federation' of June 13,1996 (28 amended on 13.07.2015). Collection of Legislative Acts of the Russian Federation. 17.06.1996. No. 25. Art. 2955. 
ловиной тысячи рублей, будет совершено во второй раз по истечении данного срока, то деяние подлежит квалификации вновь по статьи 7.27 КоАП РФ. Здесь весьма важным является систематизированный подход к учету количества и сроков привлечения нарушителя ответственности.

В большинстве случаев для квалификации деяния в качестве уголовно наказуемого важным признаком является неоднократность, которая весьма по-разному трактуется законодателем. В некоторых случаях необходимо обращать внимание на примечания к статьям УК РФ либо изучать практику судебного толкования при квалификации деяния. Анализируя законодательный подход к применению административно-преюдициальных норм при неоднократности совершения деяний, можно обозначить следующие особенности.

1. Неоднократность совериения административных правонарушений - как квалифицирующий признак состава уголовно наказуемого деяния при совершении аналогичного деяния лицом, ранее подвергнутым админи стративному наказанию.

В качестве примера можно привести составы статьи 5.35.1 КоАП РФ (неуплата средств на содержание детей или нетрудоспособных родителей) и статьи 157 УК РФ (неуплата средств на содержание детей или нетрудоспособных родителей).

В данном случае законодатель в примечании к статье 157 УК РФ закрепил понятие неоднократности как совершение аналогичного деяния лицом, подвергнутым административному наказанию. Для квалификации в качестве уголовно наказуемого деяния достаточно совершить проступок, предусмотренный статьей 5.35.1 КоАП РФ во второй раз. Важным является срок, равный одному году, который исчисляется по правилам статьи 4.6 КоАП РФ с момента вступления в законную силу постановления по делу о назначении административного наказания за первое нарушение

Еще одним примером являются парные составы части 2.1 статьи 14.16 КоАП РФ (нарушение правил продажи этилового спирта, алкогольной и спиртосодержащей продукции) и статьи 151.1 УК РФ (розничная продажа несовершеннолетним алкогольной продукции). Заметим, что в примечании к статье 151.1 УК РФ акже закреплено понятие неоднократности, признаком которого является совершение лицом, подвергнутым административному анию за аналогичное деяние, в период, когда ицо считается подвергнутым административному наказанию.

Фактически повторность, как отягчающее административную ответственность обстоягельство, трансформировалась в нормы уголового законодательства при квалификации преступлений, когда за совершение административного правонарушения во второй раз деяние подлежит квалификации по УК РФ: в КоАП РФ при определении повторности речь идет о признаке однородности, а в УК РФ - об аналогичном правонарушении. Вопрос о применении административно-преюдициальных норм в уголовном законодательстве, по мнению ряда ученых, требует более пристального внимания и изучения практики применения $[9 ; 10]$, особенно по статье 264.1 УК РФ $[11 ; 21 ; 22]$. Представляется, что в сфере внедрения административно-преюдициальных норм в уголовное законодательство содержательное значение признаков повторности должно быть более конкретизировано с учетом комплексного подхода и приведено к единому критерию, ислючая разноплановые варианты толкования понятийного аппарата квалифицирующих признаков составов.

2. Неоднократность совершения административного правонарушения - как квалифицирующий признак состава уголовно наказуемого деяния при совершении лицом дважды и более двух раз административных правонарушений в течение установленного законе срока.

В качестве примера можно привести парные составы статьи 19.24 КоАП РФ (несоблюдение административных ограничений и невыполнение обязанностей, устанавливаемых при административном надзоре) и статьи 314.1 УК РФ (уклонение от административного надзора или неоднократное несоблюдение установленых судом в соответствии с федеральным законом ограничения или ограничений). При квалификации данных составов важным являетс примечание к статье 314.1 УК РФ, согласно когорому закреплено понятие неоднократности совершения правонарушения. Неоднократность применяется при условии, что лицо ранее при- after the above period expired, then the offens should again be qualified as per part 2 of Article 7.27 of the RF AOC. In this case, a very importan aspect is a systematic approach to recording the number of cases and the periods of holding the offender liable.

In the majority of cases, an important factor for qualifying the offense is duplicity. It is interpreted by the legislator in various ways. In some cases, it is necessary to refer to notes to the article of the RF CC, or to study the practice of judicial interpretation for qualifying offenses. The analysi of the legislative approach to applying administrative-prejudicial norms when offenses are committed repeatedly shows the following special features.

1. Duplicity of the administrative offense as a qualifying criterion of the elements of a crim nally punishable act when committed by an individual who has previously been held administratively liable for an analogous offense.

An example of this can be found in such elements as those provided for in Article 5.35.1 of the RF AOC (failure to pay for maintenance of children and physically disabled parents) and Article 157 of the RF Criminal Code (malicious evasion of the payment of money for the maintenance of children or physically disabled parents)

In this case, the legislator defined duplicity in the note to Article 157 of the RF Criminal Code as commitment of the analogous offense by an indiidual already penalized with administrative punishment. For qualifying an offense as a criminally punishable act, it is sufficient to commit the offense covered by Article 5.35.1 of the RF AOC for the second time. What is important is the one-yea period which is calculated in accordance with rules of Article 4.6 of the RF AOC, starting from the moment when the decision on the imposition of dministrative punishment for the first offense enters into its legal force

One more example is such double elements as those in part 2.1 of Article 14.16 of the RF AOC (violating the rules of selling ethyl alcohol, alcohol products and alcohol-containing products) and $\mathrm{Ar}-$ ticle 151.1 of the RF Criminal Code (retail sale of alcoholic products to minors). Let us keep in mind that note to Article 151.1 of the RF Criminal Code also gives a definition of duplicity, with such criterion as commitment of an offense by a person who was already penalized with administrative punishment for an analogous offense during the period when a person is considered to be subjected to administrative punishment.

It appears that repetition as a circumstance aggravating administrative liability has transformed into the norms of criminal legislation for qualifying offenses, when an administrative offense committed for the second time is subject to qualification as per the RF Criminal Code. However, when defining repetition, the RF AOC applies the criterion of similar nature, while the RF Criminal Code speaks about an analogous offense. In the opinion of some scientists, the question of applying administrative-prejudicial norms in criminal legislation requires a more focused attention and studying the practice of application $[9,10]$, especially with regard to Article 264.1 of the RF Criminal Code $[11,21,22]$. Seemingly, in the sphere of introducing administrative-prejudicial norms into criminal legislation, the substantial meaning of the repetition criteria should be concretized with the account for the complex approach, and should be reduced to one criterion, excluding the multifaceted variants of interpreting the conceptual framework of the qualifying criteria of the offense elements.

2. Duplicity of the administrative offense as a qualifying criterion of the elements of a criminally punishable act in case when administrativ offenses were committed twice and more than twice within a certain period specified by law.

An example of this can be found in such double elements as: Article 19.24 of the RF AOC (failure to observe administrative limitations imposed as part of the administrative probation) and Article 314.1 of the RF Criminal Code (evading administrative supervision or multiple failure to observe the limitation(s) imposed by court in compliance with the federal law). What is important for the qualification these elements is the note to $\mathrm{Ar}$ ticle 314.1 of the RF Criminal Code, where the concept of the offense duplicity is defined. Duplicity is applied on condition that the individual was previously held administratively liable for an 
влекалось к административной ответственности за аналогичное деяние два раза в течение одного года. В связи с этим воз момента подлежит исчислению данный срок?

Представляется, что в УК РФ необходимо конкретизировать период исчисления данного срока, например установить, что для квалификации по статье 314.1 УК РФ при определении неоднократности применяется срок, в течение которого лицо считается подвергнутым административному наказанию по нормам статьи 4.6 КоАП РФ с момента вступления в законную силу постановления о назначении административного наказания по статье 19.24 КоАП РФ за совершение правонарушения в первый раз. Вполне целесообразным было бы установить в статье 314.1 УК РФ в качестве квалифицирующего признака совершения административного правонарушения по статье 19.24 КоАП РФ в третий раз в период действия срока, когда лицо считается подвергнутым наказанию в течение одного года по нормам статьи 4.6 КоАП РФ. Конкретизация норм позволит существенным образом упорядочить и упростить практику квалификации деяний.

Интересным также является еще один вариант парных составов: статья 20.2 КоАП РФ (нарушение установленного порядка организации либо проведения собрания, митинга, демонстрации, шествия или пикетирования) статья 212.1 УК РФ (неоднократное нарушение установленного порядка организации либо проведения собрания, митинга, демонстрации, шествия или пикетирования). Здесь прослеживается многоступенчатый подход законодателя к установлению ответственности за повторное совершение деяний.

С одной стороны, при квалификации по статье 212.1 УК РФ важным признаком является неоднократность совершения деяния лицом которое ранее привлекалось к административной ответственности по статье 20.2 КоАП РФ более двух раз в течение ста восьмидесяти дней. В данном случае примечание к статье 212.1 УК РФ закрепляет особый порядок исчисления срока административной наказанности, нежели чем это предусмотрено в статье 4.6 КоАП РФ. При этом не ясен порядок исчисления данного срока.

Наряду с этим в части 8 статьи 20.2 КоАП РФ повторность закреплена в качестве само- стоятельного квалифицирующего признака состава нарушения. В данном случае применяетс правило статьи 4.6 КоАП РФ и действует срок, в течение которого лицо считается подвергнутым административному наказанию, равный одному году.

Подобное разнообразие формулировок и отсутствие четкой регламентации значительно усложняют правоприменительную практику. Фактически получается, что для квалификации по уголовному закону нарушитель должен быть привлечен к административной ответственности более двух раз, а это с юридической точки зрения понимается как три раза и более. Заметим, что законодатель в примечании к стать 212.1 УК РФ ведет речь не о периоде подвергнутости к административной ответственности, a о фактах привлечения к административной ответственности.

В соответствии с КоАП РФ лицо может считаться ранее привлеченным к административной ОтветственНости, НО прН этом срок нав состоянии административной наказанности к моменту совершения последующих нарушений может быть погашен А вот для применения отягчающего обстоятельства и квалификации в качестве повторно совершенного деяния важным является срок, в течение которого лицо считается подвергнутым наказанию. Поэтому представляется, что формулировка примечания статьи 212.1 УК РФ с этой позиции является не совсем корректной применительно к положениям статьи 4.6 КоАП РФ. Также необходимо отметить, что для привлечения к административной ответственности по признаку повторности на основании части 8 статьи 20.2 КоАП РФ достаточно совершить деяние во второй раз в течение срока, предусмотренного статьей 4.6 КоАП РФ.

В связи с этим возникает вопрос: для квалификации по статье 212.1 УК РФ необходимо трижды быть привлеченным по части 8 стать 20.2 КоАП РФ или в комाлексе П10 8 соб̆ восьми частей статьи 20.2 КоАП РФ? К сожалению, этот вопрос остается открытым. Если вникнуть в смысл квалифицирующих признаков статьи 212.1 УК РФ, то на практике можег получиться так, что нарушитель привлекается один раз за впервые совершенное нарушение по статье 20.2 КоАП РФ. Затем дважды - по части 8 статьи 20.2 КоАП РФ, как за второй третий раз по признаку повторности с соблю-

Telegin A. S., Tiunova N. V.

analogous offense twice within one year. In light of this, there arises a question about the momen from which this period shall begin.

Seemingly, the RF Criminal Code should specificate the period for the computation; for example, it should establish that for qualifying an offense as per Article 314.1 of the RF Criminal Code, the period should be applied within which the individual is considered to be subjected to administrative punishment in accordance with the rules of Article 4.6 of the RF AOC, from the moment when the decision on the administrative punishment came into its legal force as indicated in Article 19.24 of the RF AOC for an offense committed for the first time. It would be reasonable if Article 314.1 of the RF Criminal Code could establish the qualifying criterion for the offense covered by 19.24 of the RF AOC committed for the third time during the period when the individual is considered to be subjected to administrative punishment for one year in accordance with the rules of Article 4.6 of the RF AOC. The specification of the norms would make it possible to significantly systematize and simplify the practice of qualifying offenses.

Another interesting variant of double element is represented by Article 20.2 of the RF AOC (violation of the established procedure for arranging or conducting a meeting, rally, procession or picket) and Article 212.1 of the RF Criminal Code (multiple violation of the established procedure for arranging or conducting a meeting, rally, procession or picketing). In this case, there can be seen a multi-staged approach of the legislator to defining the extent of liability for a repeat offense

On the one hand, when qualifying an offens as per Article 212.1 of the RF Criminal Code, an important criterion is duplicity in the commitment of the offense by a person who was previously held administratively liable in accordance with Article 20.2 of the RF AOC more than twice within the period of one hundred and eighty days. In thi case, the note to Article 212.1 of the RF Criminal Code defines a special procedure for calculating the period of being administratively punished as compared to the procedure provided for by Article 4.6 of the RF AOC. However, the procedure of calculating this period is not clear.

Along with that, part 8 of Article 20.1 of the RF AOC establishes repetition as a separate quali- fying criterion of the elements of an offense. In this case, the rule of Article 4.6 of the RF AOC is applied, and there is established one-year period as a period during which the person is considered to be subjected to with administrative punishment.

Such a variety of definitions and the absence of clear regulation significantly complicates law enforcement. It appears that to qualify an offense under criminal law, the offender should have been penalized with administrative punishment more than twice, which is understood from the juridical point of view as three and more times. Let us note that in the note to Article 212.1 of the RF Criminal Code the legislator speaks not about the period of being subjected to administrative punishment but about the facts of being held administratively liable.

An individual can be considered to be previously held administratively liable in accordanc with the RF AOC, however the period of the person's being subjected to administrative punishment may have expired by the moment of committing subsequent offenses. And for applying the aggravating circumstance and qualifying an offense as repeat, the important criterion is the period during which the person is considered to be subjected to administrative punishment. Therefore, from this line of reasoning, the wording of the note to Article 212.1 of the RF Criminal Code appears to be not quite correct as applied to the regulations of Article 4.6 of the RF AOC. Moreover, it is noteworthy that for holding a person administratively liable pursuant to the repetition criterion as per part 8 of $\mathrm{Ar}$ ticle 20.2 of the RF AOC, it is sufficient for him to commit the offense for the second time within the period established by Article 4.6 of the RF AOC.

In view of this, the following question needs to be answered: for qualifying an offense as pe Article 212.1 of the RF Criminal Code, is it necessary to thrice be held liable under part 8 of Article 20.2 of the RF AOC, or under any of the eight parts of Article 20.2 of the RF AOC in complex? Unfortunately, the question remains open. If we take a close look at the essence of the qualifying criteria of Article 212.1 of the RF Criminal Code, it appears that the following situation is possible in practice. An offender was hold liable once unde Article 20.2 of the RF AOC, then twice under part 8 of Article 20.2 of the RF AOC as for repeat of fenses, with the observation of the period specified 
дением срока, предусмотренного статьей 4.6 КоАП РФ. При этом не понятно, с какого момента он должен исчислятьсл: с момента вступления в законную силу первого ния о назначении административного наказания или второго, чтобы быть привлеченным третий раз к ответственности. В итоге на четвертый раз - действия нарушителя могут быт квалифицированы по статье 212.1 УК РФ. А как правильно исчислять сто восемьдеся календарных дней, о которых речь идет в примечании статьи 212.1 УК РФ: со дня вступления в законную силу постановления по делу о назначении административного наказания за первое административное нарушение или третье, чтобы четвертое и последующие аналогичные нарушения квалифицировать согласно уголовному закону?

Учитывая общие положения статьи 4.6 КоАП РФ о повторности, этот срок необходимо исчислять со дня вступления в законную силу постановления о назначении административного наказания за первое нарушение по соответствующей части статьи 20.2 КоАП РФ. Затем при наличии вступивших в законную силу двух и более постановлений о назначении административных наказаний за последующие нарушения по признаку повторности в соответствии с частью 8 статьи 20.2 КоАП РФ можно будет вести речь о возможной квалификашии по статье 212.1 УК РФ, если, например, сто восемьдесят календарных дней не истекут со дня вступления в законную силу первого постановления о назначении административного наказания. А если этот срок истек, то вполне возможно квалифицировать каждое последующее вновь совершенное нарушение как повторное (по ч. 8 ст. 20.2 КоАП РФ), при условии, что не истек срок, предусмотренный статьей 4.6 КоАП РФ. Фактически совершение нарушений может носить систематический и длительный характер а лицо может быть привлечено не к уголовной, а только к административной ответственности. Поэтому очень важно для квалификации определить в примечании к статье 212.1 УК РФ порядок и момент исчисления срока.

Представляется, что на законодательном уровне необходимо пересмотреть такую сложную конструкцию состава статьи 212.1 УК РФ и привести в соответствие с положениями статьи 4.6 КоАП РФ, закрепив в примечании статье 212.1 УК РФ, что неоднократным при- знается совершение лицом трех административных правонарушений, предусмотренных статьей 20.2 КоАП РФ, и применяется при совершении четвертого и последующего нарушения при условии, что не истек срок, предусмотренный статьей 4.6 КоАП РФ, который исчисляется со вступления в законную силу постановления о назначении административного наказания за третье нарушение.

3. Неоднократность совершения административного правонарушения - как квалифицирующий признак состава уголовно наказуемого деяния с учетом практики судебного полкования без конкретизации в законе.

В качестве примера можно привести парные составы статьи 14.10 (незаконное использование средств индивидуализации товаров) КоАП РФ и статьи 180 (незаконное использование средств индивидуализации товаров) УК РФ

Для квалификации по статье 180 УК РФ необходимо наличие признака неоднократности совершения административного правонарушения. Однако для трактовки понимания повторности необходимо обращать внимание на акты толкования судов.

В соответствии с постановлением Пленума Верховного Суда РФ № 14 от 26 апреля 2007 «неоднократным признается совершение два более раза незаконного использования предупредительной маркировки в отношении товарного знака или наименования места происхождения товара, не зарегистрированных в Российской Федерации» ${ }^{1}$. Анализируя квалифицирующие признаки состава преступления, предусмотренного статьей 180 УК РФ, можно утверждать, что законодатель и акт судебного толкования не конкретизируют понятие неоднократности с позиции повторного совершения административного правонарушения, предусмотренного за аналогичное деяние по статье 14.10 КоАП РФ. Также в статье 180 УК РФ не закреглено, что ответственность наступает при совершении двух и более раз административного правонарушения, предусмотренного статьей 14.10 КоАП РФ, в течение срока, когда лицо, в соответствии со статьей 4.6 КоАП РФ, считается подвергнутым административному наказанию.

O практике рассмотрения судами уголовных дел о нарушеправ, а также о незаконном использовании товарного знаге постановление Пленума Верховного Суда РФ от 26 апр. 2007 г. №14»/// Бюл. Верховного Суда РФ. 2007. №7. in Article 4.6 of the RF AOC. However, it is not clear when this period begins: does it begin at the moment when the first decision on the impositio of administrative punishment comes into its legal force, or at the moment when the second decision comes into its legal force - so that the third punishment could be imposed accordingly. Finally, for the fourth time, the offender's actions can be qualified as per Article 212.1 of the RF Criminal Code. And what is the right way to calculate one hundred and eighty calendar days which are referred to in the note to Article 212.1 of the RF Criminal Code: are they calculated from the moment when the first or the third decision on the imposition of administrative punishment comes into legal force - so that the fourth and the subsequent facts of analogous offenses could be qualified under criminal law?

Taking into account the general provisions on repetition contained in Article 4.6 of the RF AOC, this period shall be calculated starting from the data when the first decision on the imposition of administrative offense comes into its legal force for the offense qualified in accordance with the corresponding part of Article 20.2 of the RF AOC. Then, in a situation when two or more decisions on the imposition of administrative punishment have already come into their legal force for committing subsequent offenses pursuant to the repetition criterion of part 8 of Article 20.2 of the RF AOC, one can speak about the possible qualification as per Article 212.1 of the RF Criminal Code, for example, in the event that one hundred and eighty days after the first decision came into legal force have not expired. If this period has expired, then every subsequent offense may be qualified as a repea one in accordance with part 8 of Article 20.2 of the RF AOC, provided that the period prescribed by Article 4.6 of the RF AOC has not expired. In fact, commitment of offenses can be of a regular an long-standing nature, while the individual can be held only administratively liable and not criminally liable. This is why it is so important to specify the procedure and the starting point for the period computation in the note to Article 212.1 of the RF Criminal Code.

Seemingly, it is necessary to legislatively revise this complicated construction of the elements of Article 212.1 of the RF Criminal Code, bring it into compliance with the provisions of Article 4.6 of the RF AOC, and establish it in the note to Ar- ticle 212.1 of the RF Criminal Code that a repeat offense is commitment by the individual of three administrative offenses specified in Article 20.2 of the $\mathrm{AOC}$, and that the repetition criterion is applied for the fourth and every subsequent offense provided that the period prescribed by Article 4.6 of the AOC and calculated from the moment of the third administrative punishment decision coming into legal force has not expired.

3. Duplicity of the administrative offense as a qualifying criterion of the elements of a criminally punishable act in the context of judicial interpretation with no concretization in law.

The example of the above can be found in such double elements as those covered in Article 14.10 of the RF AOC (unlawful use of a trade mark) and Article 180 of the RF Criminal Code (unlawful use of a trade mark).

For the qualification under Article 180 of the RF Criminal Code, the criterion of repeat commitment of an administrative offense should be applicable. However, to interpret the understanding of repetition, it is necessary to consider the acts of judicial interpretation.

Resolution of the Plenum of the RF Supreme Court of April 26, 2007 No. 14 runs that 'the unlawful use for two or more times of the warning marking with regard to the trade mark or the name of the goods place of origin which are not registered in the Russian Federation is recognized as repeat commitment ${ }^{1}$. Analyzing the qualifying criteria of the elements of the crime covered in $\mathrm{Ar}^{-}$ ticle 180 of the RF Criminal Code, one can state that the legislator and the judicial interpretation act to not concretize the notion of duplicity with regard to the repeat commitment of the administrative offense provided for by Article 14.10 of the RF AOC for an analogous conduct. Moreover, Article 180 of the RF Criminal Code does not regulate that the liability is imposed for committing two or more administrative offenses covered in Article 14.10 of the RF AOC within the period when the person is considered to be already subjected to administrative punishment as per Article 4.6 of the RF AOC.

Resolution of the Plenum of the Supreme Court of the Rustan Federation No. 14 эOn the Practice of Judicial ConsiderRights, Inventor's Rights and Patent Rights, and Unlawful Use of a Trade Markэ of April 26, 2007. Bulletin of the Supreme Court of the Russian Federation. 2007. №. 7 . 
Отсутствие четких формулировок законодателя при закреплении квалифицирующих признаков составов преступлений при непосредственной взаимосвязи с составами административных правонарушений по признаку повторности или неоднократности, а также неопределенность в части порядка исчисления периодов, в течение которых допустимо применять административно-преюдициальные нормы уголовного закона, вполне очевидно могут порождать проблемы у правоприменителя, связанные с законностью квалификации составов преступлений. В данном случае представляется, что содержательная часть статьи 180 УК РФ требует дальнейшей модернизации. Речь идет о том, что необходимо установить примечание к статье 180 УК РФ, в котором закрепить позицию Пленума Верховного Суда РФ о критериях неоднократности совершения деяния. Это позволит упорядочить правоприменительную практику с позиции оптимизации и удобства квалификации. В этом же примечании необходимо также определить порядок исчисления периода, в течение которого будет применяться признак неоднократности при совершении двух и более административных правонарушений, по статье 14.10 КоАП РФ. А именно закрепить, что для квалификации по признаку неоднократности в соответствии со статьей 180 УК РФ необходимо учитывать, что лицо должно совершить два и более раз административные правонарушения, по статье 14.10 КоАП РФ, в течение срока, предусмотренного статьей 4.6 КоАП РФ. Такая конкретизаци позволит более грамотно подойти к законодательному закреплению административнопреюдициальных норм в уголовном законе и позволит оптимизировать процесс квалификации преступлений. Отсутствие этой конкретизации может порождать на практике квалификацию деяний по признаку повторности и неоднократности в соответствии со статьей 180 УК РФ вне зависимости от того, истек или нет срок, в течение которого лицо считается подвергнутым административному наказанию по признаку повторности его совершения по нормам статьи 4.6 КоАП РФ.

Наряду с этим в некоторых парных составах прослеживается и полное отсутствие законодательного закрепления понятия неоднократности и какого-либо акта судебного толкования данно- го термина применительно к конкретному составу. В качестве примера можно привести два парных состава: статье 5.37 КоАП РФ (незаконные действия по усыновлению (удочерению) ребенка, передаче его под опеку (попечительство) или в приемную семью) и статью 154 УК РФ (незаконное усыновление (удочерение).

\section{Заключение}

В ходе исследования вопроса о многообразии законодательного подхода к определению содержания и юридического значения повторности совершения административных правонарушений важно было установить, насколько целесообразно использовать различные трактовки данного термина и как приведение этого термина к единому законодательному смыслу существенным образом сможет упорядочить и систематизировать правоприменительную практику. Представляется, что данная тема весьма не простая, требует дальнейшего обсуждения, находится на стыке административного и уголовного законодательства Российской Федерации.

Однако стоит отметить, что во многих зарубежных странах нет такого многофункционального подхода к определению юридического смысла повторности совершения деяния. В основном вид и размер назначаемого наказания зависит от формы вины, степени тяжести и может быть предусмотрено усиление назначаемого наказания, когда один из видов наказания назначен только после того, как за какое-либо деяние ранее было назначено менее тяжкое наказание. В этом смысле повторность заключается не в квалификации деяния по данному количественному признаку, а по шаговому и поэтапному выбору вида наказания. Так, например, в немецком праве санкции в виде изъятия или взыскания могут быть назначены только после применения административного штрафа $[8 ; 15]$.

В некоторых регионах США на выбор более строгого наказания влияет количественный показатель одновременного совершения нескольких нарушений. Например, в Аризоне для назначения более строгого наказания за агрессивное вожление необходимо одновременно совершить, как минимум, два проступка из довольно обширного списка: превышение скорости, игнорирование светофоров, опасное пере-
The absence of a clear wording when defining the qualifying criteria of the elements of crimes directly related to the elements of administrative offenses on the basis of the repetition/duplicity criterion, and the uncertainty with regard to the procedure of calculating the periods when the administrative-prejudicial norms of criminal law could be applied, can apparently cause certain problems in law enforcement associated with the legitimacy of the crime elements qualification Seemingly, in this case the substantial part of $\mathrm{Ar}-$ ticle 180 of the RF Criminal Code requires further modernization. The point is that it is necessary to introduce a note to Article 180 of the RF Criminal Code where the position of the RF Supreme Court Plenum could be states about the criterion of duplicity of committing an act. This would allow systematizing law enforcement practice from the perspective of optimization and convenience of application. Along with that, the above note should prescribe the procedure of calculating the period for which the duplicity criterion will be applied when two or more administrative offenses are committed as per Article 14.10 of the RF AOC. In particular, it should be fixed that for qualifying an offense using the criterion of duplicity as per Article 180 of the RF Criminal Code, it should be taken into account that the person has to commit two or more offenses as per Article 14.10 of the $\mathrm{RF}$ AOC within the period prescribed by Article 4.6 of the RF AOC. Such concretization would allow providing better legislative fixation of administrative prejudicial norms in criminal law and optimizing the process of qualifying crimes. The absence of this concretization can result in actua qualifying offenses as per the repetition/duplicity criterion in accordance with Article 180 of the RF Criminal Code irrespective of the expiration or the continuation of the period for which the person is considered to be subjected to administrative punishment in accordance with $t$ he rules of Article 4.6 of the RF AOC.

At the same time, some of the double elements demonstrate a total absence of legislative fixation of the duplicity concept and of any act of judicial interpretation of this term with regard to the specific elements. The example of that can be found in two double elements: Article 5.37 of the RF AOC (unlawful acts aimed at adoption of a child, or placement thereof under guardianship or with an adopting family) and Article 154 of the RF Criminal Code (illegal adoption).

\section{Conclusions}

As part of researching the question of the versatility in the legislative approach to defining the scope and the juridical meaning of the administrative offense repetition, what can be discussed is the practicability of using different definitions of thi term, and the possibility of significant optimization and systematization of the law enforcement through bringing this term to a unified legal content. Seemingly, this topic is far from being simple, and requires further discussion, as it exists at the border of administrative and criminal legislation of the Russian Federation

However, it should be noted that in many foreign countries there is no such multi-functional approach to defining the juridical sense of the offense repetition. Typically, the type and the size of the imposed punishment depend on the form of the guilt, the severity and the character of the commit ted offense. Along with that, there can be imposed a more severe punishment: when one of the types of punishment can only be imposed after there wa previously imposed a less severe punishment for some offense. In this sense, repetition is not in qualifying the offense as per this quantitative criterion, but in the phase-to-phase and step-by-step choice of the type of punishment. In particular, German law prescribes application of such sanctions as seizure or prosecution only after the administrative fine was applied $[8,15]$.

In some of the U.S. regions, the choice of a more severe punishment is influenced by the quantitative criterion of committing several offense simultaneously. For example, for imposing a more severe punishment for aggressive driving in Arizona, minimum two offenses need to be committed from a rather extensive list of offenses: overspeeding, ignoring the traffic lights signals, risky lane- 
строение, езда по обочине и др. Агрессивное вождение в этом штате может привести к уголовному обвинению в мелком правонарушении. Это означает, что правонарушители могут быть подвергнуты уголовному наказанию, например штрафу до 1000 долларов либо тюремному заключению до 90 дней ${ }^{1}$.

В штате Делавэр агрессивным вождением признается совершение не двух, а трех нарушений одновременно ${ }^{2}$. Согласно закону Делавэра, тот, кто нарушает правила дорожного движения, за неосторожное вождение должен быть оштрафован за первое правонарушение на сумму не менее 100 долларов и не более 300 долларов или заключен в тюрьму на срок не менее 10 и не более 30 дней, или и то и другое. За каждое последующее аналогичное правонарушение, совершенное в течение 3 лет с момента совершения предыдущего правонарушения, лицо должно быть оштрафовано на сумму не менее 300 и не более 1000 долларов США или заключено в тюрьму на срок не менее 30 и не более 60 дней, или и то и другое, а его водительские прав должны быть приостановлены на 30 дней $^{3}$.

В Саудовской Аравии, по данным ArabNews, все, кто пойман за агрессивное вождение автомобиля в первый раз, столкнутся с судебным разбирательством и конфискацией автомобиля в течение месяца, а также штрафом около 2700 долларов (2 000 евро). За повторное агрессивное вождение наказание более суровое: автомобиль будет конфискован в течение трех месяцев, штраф будет удвоен, и грозит тюремный срок до 1 года. Если нарушение будет совершено вновь, то размер штрафа удваивается еще раз, а тюремное заключение может быть назначено на срок до 5 лет $^{4}[11]$. Наряду с этим за рубежом изучаются правовая природа и психология нарушителя при повторном агрессивном вождении [12; 13; 14; 19; 22], а также при

Aggressive Driving Laws. URL: https://www.legalmatch. com/law-library/article/aggressive-driving-laws.html (дата ббращения: 10.06.2019).

2Delaware code TITLE 21 Motor Vehicles Registration, Title er I. General/ Provisions. URL: http.delcode.delaware.go/ title21/c027/sc01/index.shtml (дата обращения: 10.06.2019) Title 21 motor vehicles operation and equipment chapter 4 rules of the road Subchapter IX. Reckless Driving; Drivin While Intoxicated/. URL: http://delcode.

${ }^{4}$ Drifting on Public Roads Becomes Criminal Offense in Saudi Arabia. URL: https://www.carscoops.com/2014/01/ driting-on-public-oads-becomes (дата обращения: 10.06.2019). совершении многочисленных и массовых краж со взломом, в том числе из жилых помещений $[16 ; 17 ; 20]$. Также поднимается вопрос о целесообразности увеличения санкций и их роли в предупреждении повторного совершения преступных деяний, решения задач по обеспечению общественного порядка и безопасности государстве [7; 18]

В постановлении Пленума Верховного Суда Республики Беларусь «О применении судами законодательства об ответственности за правонарушения против экологической безопасности и природной среды» от 18 декабря 2003 г. разъяснено, что основанием уголовной ответственности за преступления с признаками административной преюдиции является умышленное совершение виновным запрещенного уголовным законом деяния.

Этот краткий обзор о практике применения более строгого наказания за повторно совершенные административные правонарушения свидетельствует о тенденциях криминализации административных проступков и об ужесточении карательной функции государства за наиболее опасные и умышленные деяния. Поддерживая данные законодательные тенденции прелставляется необходимым систематизировать и упорядочить нормы действующего административного и уголовного законодательства России, которые регламентируют вопрось ответственности за повторно совершенные административные правонарушения.

Изучая правовую природу и юридическое содержание повторности совершения административного правонарушения в современных условиях, представляется весьма важным комплексно пересмотреть существующие нормь КоАП РФ и УК РФ и предложить на законодательном уровне систематизировать нормы действующего законодательства России следующим образом:

1) в каждой статье КоАП РФ, которая закрепляет составы административных правонарушений, предусмотреть дополнительную часть с самостоятельным квалифицирующим признаком повторности с более строгой санкцией;

2) в статье 14.55 КоАП РФ предусмотрет самостоятельный состав за повторное совершение административного правонарушения, исключив этот критерий из понятия грубого нарушения, который определен постановление Правительства Российской Федерации; change, driving the road side, and others. In this state, aggressive driving may imply criminal accusation in minor offense. This means that offenders may be penalized with criminal punishment, for example with a fine of up to USD 1,000 or imprisonment for a period of up to 90 days ${ }^{1}$.

In state Delaware, driving is recognized as aggressive in case there are committed not two but three offenses simultaneously ${ }^{2}$. According to the law of Delaware, the individual who violates the traffic rules should be punished for the first offense with a fine of at least USD 100 and not more than USD 300, or imprisoned for a period of at least 10 days and not more than 30 days, or both. For any subsequent analogous offense committed within 3 years after the previous offense was committed, the individual should be penalized with a fine of a least USD 300 and not more than USD 1,000, or imprisoned for a period of at least 30 days and no more than 60 days, or both, and his/ her driving license should be suspended for 30 days $^{3}$.

In Saudi Arabia, according to ArabNews, everybody who was stopped for aggressive driving fo the first time will be brought to the court and his/her car will be confiscated for one month, and fine of about $\$ 2,700(€ 2,000)$ will be imposed. Fo repeat aggressive driving, the punishment will be more severe, the car will be confiscated for three months, the fine will be twice increased, and there will be a risk of imprisonment for a period of 1 year. If the offense is committed again, then the fine will be twice increased again, and the individual can be sentenced to imprisonment for a perio of up to 5 years ${ }^{4}$ [11]. Along with that, foreign researchers also study the legal nature and the offender's psychology at repeat aggressive driving $[12,13,19,22]$, as well as at committing numerous and mass theft with breaking in, including theft

${ }^{1}$ Aggressive Driving Laws. Available at: https://www.legal natch.com/law-library//article/aggressive-driving-laws.html Title and Licenses. CHAPTER 27: DRIVER'S LICENSE Subchapter I: General Provisions. Available http://delcode.delaware.gov/title21/c027//sc01/index.shtml. Title 21: Motor Vehicles Operation and Equipment. Chapter 41. Rules of the Road. Subchapter IX. Reckless Driving; Drivgov/title2 $1 / \mathrm{c} 041 / \mathrm{sc} 09$

${ }^{4}$ Drifting on Public Roads Becomes Criminal Offense in Sat di Arabia. Available at: https://www.carscoops.com/2014/01/ drifting-on-public-oads-becomes. from living premises $[16,17,20]$. Moreover, there is raised a question about the feasibility of toughening sanctions and about their role in preventin repeat commitment of offenses, in solving the task on maintaining the public order and security within the state $[7,18]$.

Resolution of the Plenum of the Supreme Court of the Republic of Belarus 'On the Application by Courts of the Legislation on Liability for Offenses against Ecological Safety and Environment' of December 18, 2003 explains that the grounds for criminal liability for offenses showing the signs of administrative prejudice is the intentional commitment by the guilty person of an act prohibited by criminal law.

This short review of practice in the application of a more severe punishment for repeat administrative offenses demonstrates the tendencies of the administrative offenses criminalization and the reinforcement of the punitive function of the state with regard to the most dangerous acts and intentional acts. While supporting these legislative tendencies, we deem it necessary to systematize an optimize the norms of the current administrative and criminal legislation of Russia which regulate the issues of liability for repeat administrative of fenses.

When studying the legal nature and the juridical content of the administrative offense repetitio in modern conditions, it seems important to revise in complex the existing norms of the RF AOC and the RF Criminal Code. Based on the analysis performed, we deem it appropriate to propose the folowing measures to systematize the norms of the current Russian legislation:

1) every article of the RF AOC which cover the elements of administrative offenses should be supplemented with an additional part with an independent qualifying criterion of repetition with more severe sanction;

2) Article 14.55 of the RF AOC should be supplemented with an independent element for the repeat commitment of the administrative offense this criterion should be excluded from the definition of gross violation introduced by the Resolution of the Government of the Russian Federation; 
3) во всех случаях применения административно-преюдициальных норм в уголовном законодательстве России установить единый квалифицирующий признак неоднократности, под которым следует понимать совершение правонарушения лицом, ранее подвергнутым административному наказанию за аналогичное деяние более двух раз, в период срока, предусмотренного статьей 4.6 КоАП РФ;

4) систематизировать все имеющиеся акть судебного толкования по вопросам об определении понятия повторности, аналогичности, однородности, а также систематического совершения административного правонарушения, а также постановления Правительства Российской Федерации и федеральные законы, включив единое понимание термина повторности в КоАП РФ;

5) нормы УК РФ, закрепляющие составь административно-преюдициального характер и содержащие такой квалифицирующий признак, как неоднократность, привести в соответствие с правилами статьи 4.6 КоАП РФ;

6) пересмотреть компетенцию административно-юрисдикционных органов, уполномоченных рассматривать дела об административных правонарушениях, предоставив право назначать административное наказание за впервые совершенное деяние должностным лицам органов исполнительной власти, а все материалы с квалифицирующим признаком повторности совершения административного правонарушения передать в исключительные полномочия судов;

7) создать единую централизованную базу данных органов исполнительной и судебной власти по делам об административных правонарушениях в отношении лиц, подвергнутых административному наказанию, для упорядочения и упрощения квалификации деяния в качестве повторного

Представляется, что эти предложения по совершенствованию современного законодательства России позволят оптимизировать процесс квалификации составов повторных административных правонарушений, в том числе при применении административно-преюдициальных норм в уголовном законодательстве России.

\section{Библиографический список}

1. Бежанов В. О. Особенности применения повторности как квалифицирующего признака административного правонарушения Вестник РГГУ. Юридические науки. 2013. № 19 (120). C. $82-87$.

2. Кобзарь-Фролова М. Н. Проблемы назначения административных наказаний за правонарушения, совершенные физическим лицом повторно // Уголовно-исполнительное право 2017. T. 12(1-4), № 4. C. 498-501.

3. Масленников М. Я. Повторность как квалифицирующий признак административного правонарушения // Закон. 2008. Ng 9. С. 43-51.

4. Малков В. П. Неоднократность правонарушения и административная преюдиция как средства криминализации и декриминализации содеянного в Российском уголовном праве // Библиотека криминалиста. 2013. № 2(27) C. $179-186$.

5. Обухова Т. В. К вопросу о некоторых особенностях конструирования норм с административной преюдицией // Вестник Уральского юридического института МВД России. 2018. № 2. C. 83-85.

6. Сидоренко Э. Л. Административная преюдиция в уголовном праве: проблемы правоприменения // Журнал российского права воприменения // Жур 6. С. 128-130.

7. Тарбагаев А. Н. Административная ответственность в уголовном праве // Правоведение. 1992. № 2. С. 62-68.

8. Татарян В. Г., Магомедов Б. М. Опы решения проблем административной ответственности в современном законодательстве ФРГ // Вестник Уральского института экономики, управления и права. 2012. № 2 (19). С. 49-61.

9. Харлова М.И. Особенности состава преступления с административной преюдицией // Актуальные проблемы российского права. 2016. № 8 (69). C. 136-143.

10. Чикин Д. С. Преступление с административной преюдицией как вид сложного единичного преступления // Российский следователь. 2012. № 23 . С. 17-18

11. Agildin $V . V$. Some aspects of the criminal law policy of cjunteracting traffic crimes (Using the example of art. 264.1 of the Criminal Code). journal of criminology. 2016 . gy. 2016. Vol. 10.

12. Bjornebekk G. Dispositions related to sensitivity in the neurological basis for Disposition
3) for all the cases of applying administrativeprejudicial norms in the criminal legislation of Russia, there should be established a unified qualifying criterion of duplicity, which should be understood as commitment of the offense by the person who was previously penalized with administrative punishment for an analogous offense mor than twice within the period prescribed by Article 4.6 of the RF AOC;

4) to systematize all the existing acts of juridical interpretation on defining the concepts of repetition, analogousness, similar nature, and the concept of systematic commitment of the administrative offense, and also to systematize resolutions of the Government of the Russian Federation and federal laws, and to introduce the unified definition of repetition into the RF AOC;

5) norms of the RF Criminal Code which define the administrative-prejudicial elements an contain such qualifying criterion as repetition should be brought in compliance with the rules of Article 4.6 of the RF AOC;

6) to revise the competence of administrativejurisdiction bodies authorized to review administrative offense cases, and grant them with the rights to impose administrative punishment for the first offense committed by an official of the executive power body, and transfer all the materials with the qualifying criterion of the administrative offense repetition to the exclusive authority of the courts;

7) to develop a unified centralized database of administrative offense cases against individual already penalized with administrative punishment, for using by executive and judicial authorities in order to systematize and simplify qualifying offenses as repeat.

Seemingly, these proposals on improving the current Russian legislation would make it possible to optimize the procedure for qualifying the elements of repeat administrative offenses, including situations when administrative-prejudicial norms are applied in criminal legislation of Russia.

\section{References}

1. Bezhanov V. O. Osobennosti primeneniya povtornosti kak kvalificiruyuschego priznaka administrativnogo pravonarusheniya [Peculiarities of Use of Repeatability as a Qualifying Characteristic of an Administrative Offence]. Vestnik RGGU. Seriya 'Yuridicheskie nauki' - RSUH/RGGU Bulletin. Series: Law. 2013. Issue 19 (120). Pp. 82 87. (In Russ.).

2. Kobzar'-Frolova M. N. Problemy naznacheniya administrativnykh nakazaniy za pravonarusheniya, sovershennye fizicheskim licom povtorno [The problems of Giving Administrative Penalties for Second Offences]. Ugolovno-ispolnitel'noe pravo - Penal Law. 2017. Vol. 12 (1-4). Issue 4. Pp. 498-501. (In Russ.)

3. Maslennikov M. Ya. Povtornost' kak kvalificiruyuschiy priznak administrativnogo pravonarusheniya [Repetition as a Qualificatory Sign of an Administrative Offense]. Zakon - ZAKON. 2008. Issue 9. Pp. 43-51. (In Russ.).

4. Malkov V. P. Neodnokratnost' pravonarusheniya $i$ administrativnaya preyudiciya kak sredstva kriminalizacii i dekriminalizacii sodeyannogo $v$ Rossiyskom ugolovnom prave [Repeatedness of Offences and Administrative Prejudice as Means of Criminalization or Decriminalization of Deeds Committed in the Russian Criminal Law] Biblioteka kriminalista - Criminalist's Library. 2013. Issue 2(7). Pp. 179-186. (In Russ.).

5. Obukhova T.V. K voprosu o nekotorykh osobennostyakh konstruirovaniya norm $s$ administrativnoy preyudiciey [Some Peculiarities of the Construction of Norms with Administrative Prejudice]. Vestnik Ural'skogo Yuridicheskogo instituta MVD Rossii - Bulletin of the Ural Law Institute of the Ministry of the Interior of the Russian Federation. 2018. Issue 2. Pp. 83-85. (In Russ.).

6. Sidorenko E. L. Administrativnaya preyudiciya $v$ ugolovnom prave: problemy pravoprimeneniya [Administrative Prejudice in Criminal Law: Law Enforcement Problems]. Zhurnal rossiyskogo prava - Journal of Russian Law. 2016. Issue 6. Pp. 128-130. (In Russ.).

7. Tarbagaev A.N. Administrativnaya otvetstvennost' $v$ ugolovnom prave [Administrative Liability in Criminal Law]. Pravovedenie - Pravovedenie. 1992. Issue 2. Pp. 62-68. (In Russ.)

8. Tataryan V. G., Magomedov B. M. Opyt resheniya problem administrativnoy otvetstvennosti v 
related to sensitivity in neurological basis for activation of approach avoidance motivation, antisocial attributes and individual differences in aggres2007. Vol. 35, № 9. Pp. 1251-1263.

13. Deka D., Brown Ch. What do planning professionals, police and pedestrians in Genera think about distracted driving and walking? Transport Research Record. 2016. № 2582 . Pp. $42-50$.

14. Dula Ch. S., Dwyer W. O., LeVerne G. Policing the drunk driver: Measuring law enforcement involvement in reducing alcohol-impaired driving // Journal of safety research. 2007. Vol. 38 № 3. Pp. 267-272.

15. Geller E. The Law on Violations of the Order. 14th ed. Munich: BEC, 2006. $130 \mathrm{p}$

16. Groff E., Taniguchi T. Quantifying Crime Prevention Potential of Near-Repeat Burglary Police quarterly. 2019. Vol. 22, № 3. Pp. 330-359.

17. Groff E., Taniguchi T. Using citizen notification to interrupt near-repeat residential burglary patterns: the micro-level near-repeat experiment $/ /$ Journal of Experimental Criminology. 2019. Vol. 15, № 2. Pp. 115-149.

18. Polo Roca A. Analysing certain violation provided for in the organic law on the protection of public safety involving the security forces // Revista catalana de dret public. 2019. № 58. Pp. 195-207.

19. Raub R. A., Wark R. I., Lucke R. E. Seeking a reduction in aggressive driving through different strategies // Transport Research Record of the Transportation Research Board. 2002. № 1 Pp. 22-29

20. Stokes N., Clare J. Preventing near-repeat residential burglary through cocooning: post hoc evaluation of a targeted police-led pilot interven2019. Vol. 32, № 1 . Pp. 45-62.

21. Shevchenko O. A., Ilyin I. V. Problems of realization of institute of the administrative preyuditsa at qualification and investigation of violation of the rules of traffic by the person subjected to administrative inal code of Russian Federation) // Legal Science and Practice-Bulletin of Nizniy Novgorod Academy of the Ministry If the Interior of Russia. 2016. № 2. Pp. 156-161.

22. Zhmurov D. V. Criminal drink-driving: look of a law enforcement agent and perspective of prevention // Tomsk State University Journal. 2018. № 430. Pp. 174-179.

\section{References}

1. Bezhanov V. O. Osobennosti primeneniy povtornosti kak kvalificiruyuschego priznaka administrativnogo pravonarusheniya [Peculiarities of Use of Repeatability as a Qualifying Characteristic of an Administrative Offence]. Vestnik RGGU. Seriya 'Yuridicheskie nauki' - RSUH/RGGU Bulletin. Series: Law. 2013. Issue 19 (120). Pp. 82 87. (In Russ.).

2. Kobzar'-Frolova M. N. Problemy naznacheniva administrativnykh nakazaniy za pravonarusheniya, sovershennye fizicheskim licom povtorno [The problems of Giving Administrative Penalties for Second Offences]. Ugolovno-ispolnitel'noe pravo - Penal Law. 2017. Vol. 12 (1-4). Issue 4. Pp. 498-501. (In Russ.)

3. Maslennikov M. Ya. Povtornost' kak kvalificiruyuschiy priznak administrativnogo pravonarusheniya [Repetition as a Qualificatory Sign of an Administrative Offense]. Zakon - ZAKON. 2008. Issue 9. Pp. 43-51. (In Russ.).

4. Malkov V. P. Neodnokratnost' pravonarusheniya $i$ administrativnaya preyudiciya $k a k$ sredstva kriminalizacii i dekriminalizacii sodeyannogo $v$ Rossiyskom ugolovnom prave [Repeatedness of Offences and Administrative Prejudice as Means of Criminalization or Decriminalization of Deeds Committed in the Russian Criminal Law]. Biblioteka kriminalista - Criminalist's Library. 2013. Issue 2(7). Pp. 179-186. (In Russ.)

5. Obukhova T.V. K voprosu o nekotorykh osobennostyakh konstruirovaniya norm s administrativnoy preyudiciey [Some Peculiarities of the Construction of Norms with Administrative Prejudice]. Vestnik Ural'skogo Yuridicheskogo instituta MVD Rossii - Bulletin of the Ural Law Institute of the Ministry of the Interior of the Russian Federation. 2018. Issue 2. Pp. 83-85. (In Russ.).

6. Sidorenko E. L. Administrativnaya preyudiciya $v$ ugolovnom prave: problemy pravoprimeneniya [Administrative Prejudice in Criminal Law: Law Enforcement Problems]. Zhurnal rossiyskogo prava - Journal of Russian Law. 2016. Issue 6. Pp. 128-130. (In Russ.).

7. Tarbagaev A.N. Administrativnaya otvetstvennost' $v$ ugolovnom prave [Administrative Liability in Criminal Law]. Pravovedenie - Pravovedenie. 1992. Issue 2. Pp. 62-68. (In Russ.).

8. Tataryan V. G., Magomedov B. M. Opyt resheniya problem administrativnoy otvetstvennosti v sovremennom zakonodatel'stve FRG [An Attemp of Administrative Responsibility Problem-Solving in the Modern FRG Law]. Vestnik Ural'skogo instituta ekonomiki, upravleniya i prava - Bulletin of the Ural Institute of Economics, Management an Law. 2012. Issue 2 (19). Pp. 49-61. (In Russ.).

9. Kharlova M. I. Osobennosti sostava prestupleniva s administrativnoy preyudiciey [Features of the Elements on an Offence with Administrative Prejudicial Effect]. Aktual'nye problemy rossiyskogo prava - Actual Problems of Russian Law. 2016. Issue 8 (69). Pp. 136-143. (In Russ.)

10. Chikin D. S. Prestuplenie s administrativnoy preyudiciey kak vid slozhnogo edinichnogo prestupleniva [A Crime with an Administrative vidual Crime]. Rossiyskiy s. nvestigator. 2012. Issue 23. Pp. 17-18. (In Russ.)

11. Agildin $V$. V. Some aspects of the criminal law policy of cjunteracting traffic crimes (Using the example of art. 264.1 of the Criminal Code). Russian journal of criminology. 2016 Vol. 10. Issue 1. Pp. 117-125. (In Eng.)

12. Bjørnebekk G. Dispositions related to sensitivity in the neurological basis for activation of approach-avoidance motivation, antisocia attributes and individual differences in aggressive behavior. SOCIAL BEHAVIOR AND PERSONALITY. 2007. Vol. 35. Issue 9. Pp. 1251-1263. (In Eng.)

13. Deka D., Brown Ch. What do planning professionals, police and pedestrians in genera think about distracted driving and walking? Transportation Research Record: Journal of the Transportation Research Board. 2016. Issue 2582. Pp. 42-50. (In Eng.)

14. Dula Ch.S., Dwyer W.O., LeVerne G. Policing the drunk driver: Measuring law enforcement involvement in reducing alcohol-impaired driving. Journal of Safety Research. 2007. Vol. 38 Issue 3. Pp. 267-272. (In Eng.)

15. Geller E. The Law on Violations of the Order. 14th ed. Munich: BEC, 2006. 130 p. (In Eng.).

16. Groff E., Taniguchi T. Quantifying Crim Prevention Potential of Near-Repeat Burglary. Police Quarterly. September 2019. Vol. 22. Issue 3. Pp. 330-359. (In Eng.).

17. Groff E., Taniguchi $T$. Using citizen notification to interrupt near-repeat residential burglary patterns: the micro-level near-repeat experiment Journal of Experimental Criminology. June 2019. Vol. 15. Issue 2. Pp. 115-149. (In Eng.)
18. Polo Roca A. Analysing certain violation provided for in the organic law on the protectio of public safety involving the security forces. Revista Catalana de Dret Públic. June 2019. Issue 58. Pp. 195-207. (In Eng.).

19. Raub R. A., Wark R. I., Lucke R. E. Seeking a reduction in aggressive driving through different strategies. Transportation Research Record: Journal of the Transportation Research Board. 2002. Issue 1. Pp. 22-29. (In Eng.).

20. Stokes N., Clare J. Preventing near-repeat residential burglary through cocooning: post hoc evaluation of a targeted police-led pilot intervention. Security Journal. March 2019. Vol. 32. Issue 1. Pp. 45-62. (In Eng.).

21. Ilyin I. V., Shevchenko O. A. Problems of realization of institute of the administrative prejudice at qualification and investigation of violation of the rules of traffic by the person subjected to administrative punishment (art. 264.1 of the Criminal code of Russian Federation). Legal Science and Practice: Journal of Nizny Novgorod Academy of the Ministry of Internal Affairs of Russia. 2016. Issue 2. Pp. 156-161. (In Eng.)

22. Zhmurov $D$. $V$. Criminal drink-driving: look of a law enforcement agent and perspectives of prevention. Tomsk State University Journa 2018. Issue 430. Pp. 174-179. (In Eng.)

\section{References in Russian}

1. Бежанов В. О. Особенности применения повторности как квалифицирующего признака административного правонарушения Вестник РГГУ. Юридические науки. 2013. № 19 (120). C. 82-87.

2. Кобзарь-Фролова М. Н. Проблемы назначения административных наказаний за правонарушения, совершенные физическим лицом овторно // Уголовно-исполнительное право 2017. T. 12(1-4), № 4. С. 498-501.

3. Масленников М. Я. Повторность как квалифицирующий признак административного правонарушения // Закон. 2008. № 9. С. 43-51.

4. Малков В. П. Неоднократность правонарушения и административная преюдиция как средства криминализации и декриминализации содеянного в Российском уголовном праве Библиотека криминалиста. 2013. № 2(27). C. $179-186$

5. Обухова Т. В. К вопросу о некоторых особенностях конструирования норм с административной преюдицией // Вестник Уральского 
sovremennom zakonodatel'stve FRG [An Attempt of Administrative Responsibility Problem-Solving in the Modern FRG Law]. Vestnik Ural'skogo in stituta ekonomiki, upravleniya i prava - Bulletin of the Ural Institute of Economics, Management and Law. 2012. Issue 2 (19). Pp. 49-61. (In Russ.).

9. Kharlova M. I. Osobennosti sostava prestupleniva s administrativnoy preyudiciey [Features of the Elements on an Offence with Administrative Prejudicial Effect]. Aktual'nye problemy rossiyskogo prava - Actual Problems of Russian Law. 2016. Issue 8 (69). Pp. 136-143. (In Russ.).

10. Chikin D. S. Prestuplenie s administrativnoy preyudiciey kak vid slozhnogo edinichnogo prestupleniya [A Crime with an Administrative Collateral Estoppel as a Type of a Difficult Individual Crime]. Rossiyskiy sledovatel' - Russian Investigator. 2012. Issue 23. Pp. 17-18. (In Russ.).

11. Agildin V. V. Some aspects of the criminal law policy of cjunteracting traffic crimes (Using the example of art. 264.1 of the Crimina Code). Russian journal of criminology. 2016 Vol. 10. Issue 1. Pp. 117-125. (In Eng.)

12. Bjørnebekk G. Dispositions related to sensitivity in the neurological basis for activation of approach-avoidance motivation, antisocia attributes and individual differences in aggressive behavior. SOCIAL BEHAVIOR AND PERSONALITY. 2007. Vol. 35. Issue 9. Pp. 1251-1263. (In Eng.)

13. Deka D., Brown Ch. What do planning professionals, police and pedestrians in genera think about distracted driving and walking? Transportation Research Record: Journal of the Transportation Research Board. 2016. Issue 2582 Pp. 42-50. (In Eng.)

14. Dula Ch.S., Dwyer W.O., LeVerne G. Policing the drunk driver: Measuring law enforcement involvement in reducing alcohol-impaired driving. Journal of Safety Research. 2007. Vol. 38 Issue 3. Pp. 267-272. (In Eng.)

15. Geller $E$. The Law on Violations of the der. 14th ed. Munich: BEC, 2006. 130 p. (In Eng.).

16. Groff E., Taniguchi T. Quantifying Crime Prevention Potential of Near-Repeat Burglary. Police Quarterly. September 2019. Vol. 22. Issue 3. Pp. 330-359. (In Eng.).

17. Groff E., Taniguchi $T$. Using citizen notification to interrupt near-repeat residential burglary patterns: the micro-level near-repeat experiment. Journal of Experimental Criminology. June 2019. Vol. 15. Issue 2. Pp. 115-149. (In Eng.)

18. Polo Roca A. Analysing certain violations provided for in the organic law on the protection of public safety involving the security forces. Revista Catalana de Dret Públic. June 2019. Issue 58. Pp. 195-207. (In Eng.)

19. Raub R. A., Wark R. I., Lucke R. E. Seeking a reduction in aggressive driving through different strategies. Transportation Research Record: Journal of the Transportation Research Boord. arch Board.

20. Stokes N., Clare J. Preventing near-repeat residential burglary through cocooning: post hoc evaluation of a targeted police-led pilot intervention. Security Journal. March 2019. Vol. 32. Issue 1. Pp. 45-62. (In Eng.).

21. Ilyin I. V., Shevchenko O. A. Problems of realization of institute of the administrative prejudice at qualification and investigation of violation of the rules of traffic by the person subjected to administrative punishment (art. 264.1 of the Criminal code of Russian Federation). Legal Science and Practice: Journal of Nizny Novgorod Academy of the Ministry of Internal Affairs of Russia. 2016. Issue 2. Pp. 156-161. (In Eng.)

22. Zhmurov D. V. Criminal drink-driving: a look of a law enforcement agent and perspectives of prevention. Tomsk State University Journa 2018. Issue 430. Pp. 174-179. (In Eng.)

Telegin A. S., Tiunova N. V.

юридического института МВД России. 2018 № 2. C. $83-85$.

6. Сидоренко Э. Л. Административная преюдиция в уголовном праве: проблемы правоприменения // Журнал российского права 2016. № 6. C. 128-130.

7. Тарбагаев А. Н. Административная ответственность в уголовном праве // Правоведение. 1992. № 2. С. 62-68.

8. Татарян В. Г., Магомедов Б. М. Опыт решения проблем административной ответственности в современном законодательстве ФРГ // Вестник Уральского института экономики, управления и права. 2012. № 2 (19). С. 49-61.

9. Харлова М. И. Особенности состав преступления с административной преюдицией // Актуальные проблемы российского права 2016. № 8 (69). С. 136-143.

10. Чикин Д. С. Преступление с административной преюдицией как вид сложного единичного преступления // Российский следователь. 2012. № 23 . С. 17-18.

11. Agildin $V . V$. Some aspects of the criminal law policy of cjunteracting traffic crimes (Using the example of art. 264.1 of the Criminal Code) Russian journal of criminology. 2016. Vol. 10 № 1. Pp. 117-125.

12. Bjornebekk G. Dispositions related to sensitivity in the neurological basis for Disposition related to sensitivity in neurological basis for activation of approach avoidance motivation, antisocial attributes and individual differences in aggressive behavior // Social behavior and personality. 2007. Vol. 35, № 9. Pp. 1251-1263.

13. Deka D., Brown Ch. What do planning professionals, police and pedestrians in Genera think about distracted driving and walking? Transport Research Record. 2016. № 2582 Pp. $42-50$.

14. Dula Ch. S., Dwyer W. O., LeVerne G. Policing the drunk driver: Measuring law enforce- ment involvement in reducing alcohol-impaired driving // Journal of safety research. 2007. Vol. 38 , № 3. Pp. 267-272.

15. Geller E. The Law on Violations of the Order. 14th ed. Munich: BEC, 2006. $130 \mathrm{p}$

16. Groff E., Taniguchi T. Quantifying Crime Prevention Potential of Near-Repeat Burglary Police quarterly. 2019. Vol. 22, № 3. Pp. 330-359.

17. Groff E., Taniguchi $T$. Using citizen notification to interrupt near-repeat residential burglary patterns: the micro-level near-repeat experiment // Journal of Experimental Criminology. 2019. Vol. 15, № 2. Pp. 115-149.

18. Polo Roca A. Analysing certain violation provided for in the organic law on the protection of public safety involving the security forces // Revista catalana de dret public. 2019. № 58. Pp. 195-207.

19. Raub R. A., Wark R. I., Lucke R. E. Seeking a reduction in aggressive driving through different strategies // Transport Research Record of the Transportation Research Board. 2002. № 1. Pp. 22-29.

20. Stokes N., Clare J. Preventing near-repeat residential burglary through cocooning: post hoc evaluation of a targeted police-led pilot intervention // Security Journal. 2019. Vol. 32, № 1 . Pp. 45-62.

21. Shevchenko O. A., Ilyin I. V. Problems of realization of institute of the administrative preyuditsa at qualification and investigation of violation of the rules of traffic by the person subjected to administrative punishment (art. 264.1 of the Criminal code of Russian Federation) // Legal Science and Practice-Bulletin of Nizniy Novgorod Academy of the Ministry If the Interior of Russia. 2016 № 2. Pp. 156-161.

22. Zhmurov D. V. Criminal drink-driving: a look of a law enforcement agent and perspective of prevention // Tomsk State University Journal. 2018. № 430. Pp. 174-179. 